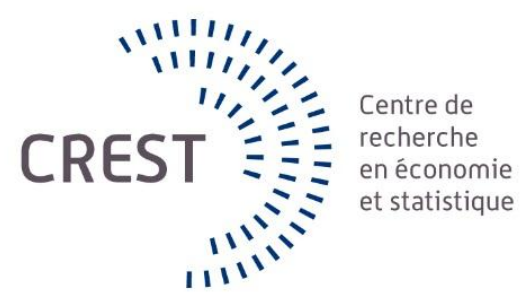

Série des Documents de Travail

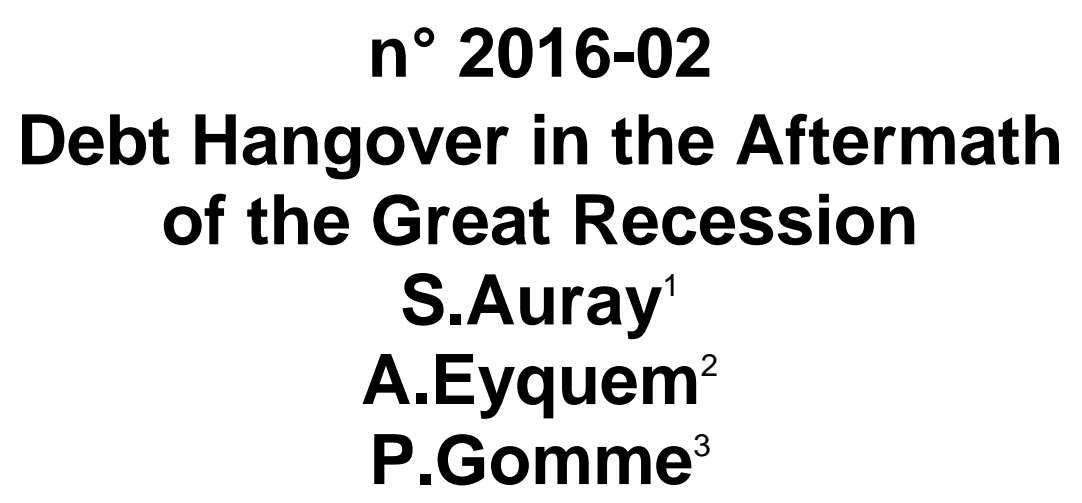

Les documents de travail ne reflètent pas la position du CREST et n'engagent que leurs auteurs. Working papers do not reflect the position of CREST but only the views of the authors.

${ }^{1}$ CREST-ENSAI and Université du Littoral Côte d'Opale. E-mail: stephane.auray@ensai.fr ${ }^{2}$ CREST-ENSAI, Université de Lyon, and GATE-LSE UMR CNRS 5824 . E-mail: aurelien.eyquem@ens-lyon.fr.

${ }^{3}$ Concordia University and CIREQ. Email: paul.gomme@concordia.ca 


\title{
Debt Hangover in the Aftermath of the Great Recession*
}

\author{
Stéphane Auray ${ }^{\dagger} \quad$ Aurélien Eyquem ${ }^{\ddagger} \quad$ Paul Gomme ${ }^{\S}$
}

January 22, 2016

\begin{abstract}
During the Great Recession, U.S. government deficits and debt levels rose sharply. What are the consequences of using alternative fiscal policy instruments to return government debt-output ratios to their pre-Great Recession values, especially in terms of welfare? This question is addressed within a dynamic general equilibrium model. The model captures key macroeconomic fluctuations from 2008 to 2014 - labor market dynamics by virtue of incorporating search and matching frictions. Armed with this model, we then contrast the effects of a post-2014 reduction of the debt-output ratio through public spending, the consumption tax rate, the labor income tax rate or the capital income tax rate. The resulting dynamics and welfare effects are very different depending on the fiscal instrument used. The welfare ranking also crucially depends on the shape of preferences for the public good in the utility function of households.
\end{abstract}

Keywords: Fiscal policies, tax reforms, government debt, government deficits. JEL Classification: E24, E37, E62.

\footnotetext{
*Corresponding author: Paul Gomme, Department of Economics, Concordia University, 1455 de Maisonneuve Blvd. West, Montréal, QC H3G 1M8, Canada. Telephone: 514-848-2424 extension 3934. Email: paul.gomme@concordia.ca

†CREST-Ensai and ULCO. Email: stephane.auray@ensai.fr

${ }^{\ddagger}$ CREST-Ensai, GATE, UMR 5824, Université de Lyon, and Université Lumière Lyon $2 . \quad$ Email: aurelien.eyquem@ens-lyon.fr

$\S$ Concordia University and CIREQ. Email: paul.gomme@concordia.ca
} 


\section{Introduction}

Among the consequences of the Great Recession was an increase in U.S. government debt, from just over $60 \%$ of GDP to over $100 \%$. This increase can be attributed to a combination of the increase in government spending associated with the fiscal stimulus package and a deterioration in the tax base. In the prevailing low real interest rate environment, the consequences of this debt increase have been relatively benign. However, as real interest rates return to their historic values, maintaining a high debt level will imply some combination of lower government spending and higher taxes. A further cost of high debt is that it places the government closer to its natural debt limit, leaving it with less maneuvering room in the face of a future economic downturn. This paper develops a dynamic general equilibrium model in order to evaluate the macroeconomic and welfare consequences of an alternative course of action: temporary fiscal austerity in order to lower the debt-output ratio. ${ }^{1}$

To set the stage for the dynamic general equilibrium model, Section 2 lays out a number of key macroeconomic facts concerning the U.S. Great Recession. There, the data are detrended with a trend line far smoother than is typically used in business cycle analysis. Several observations are of note. First, the effects of the Great Recession lingered far beyond the NBER-determined trough in June 2009. Output returned to trend only in late 2014, as did the unemployment rate. For this reason, the Great Recession is taken to refer to the period starting with the peak of the previous cycle, December 2007, through to September 2014 when output returned to trend. Second, as already noted, government spending rose quite a bit during the Great Recession - as much as 5.5\% above trend. Government expenditures subsequently fell substantially below trend - more than $6 \%$. Nonetheless, the government debt-output ratio rose precipitously. Third, the Great Recession is largely a story of the labor market. The increase and subsequent slow return of the unemployment rate to its natural rate can usefully be decomposed into two channels: the probability of separating from a job,

\footnotetext{
${ }^{1}$ In this paper, we do not consider default, either explicit or implicit through inflation. Historically, the U.S. has not resorted to explicit default. Implicit default through inflation is a possibility not explored in this paper.
} 
and the probability of finding a job. For reasons explained in Section 2, we prefer measures of these probabilities based on the Job Openings and Labor Turnover Survey (JOLTS). By this measure, the separation probability was largely unchanged during the first year of the Great Recession; it subsequently fell which, in itself, would tend to lower the unemployment rate. What accounts for the observed rise in the unemployment rate is a very rapid decline in the job-finding probability. The persistently high unemployment rate through the remainder of the Great Recession can be traced to a stubbornly low job-finding probability.

These facts, along with the goal of quantitatively analyzing the effects of various debt reduction scenarios, motivate key model features. First, so that there is a meaningful trade-off between public spending and raising taxes, public (government) spending is directly valued by households in the model while taxes are distorting. Second, in order to capture labor developments during the Great Recession, the labor market is characterized by a MortensenPissarides search-and-matching environment. Third, during the Great Recession, there are four exogenous variables driving the model's dynamics: government spending, the probability of a job separation, total factor productivity, and the cost to a firm of posting a vacancy. The first two series are taken directly from the data; the latter two are chosen so that the model matches the observed path for U.S. output and the job-finding probability.

Fiscal policy following the Great Recession is parsimoniously captured by a simple feedback rule that specifies smaller primary deficits when the debt-output ratio is above its desired or target level. More specifically, the government satisfies this fiscal policy rule by varying one policy instrument, choosing from public spending, the labor income tax, the capital income tax, and the consumption tax. This policy rule becomes operational only after the Great Recession (after September 2014).

The model is solved under the assumption of perfect foresight as a two point boundary problem. The model is first evaluated by its performance during the Great Recession. To start, replicating the path of the job-finding probability necessitates roughly a factor of four increase in the cost of a vacancy; more on this shortly. Since the model matches the job- 
finding probability and takes as given the job-separation probability, almost by construction, it mimics well the observed path of the unemployment rate. Given the path for employment, the model requires a $2.4 \%$ fall in total factor productivity between the peak and the trough in order to match the $6.2 \%$ drop in output. Capital adjustment costs ensure plausible changes in investment. The model exaggerates the fall in consumption and slightly understates the rise in the government debt-output ratio. Nonetheless, the model broadly captures observed behavior of the U.S. economy during the Great Recession.

Having gained confidence in the model by looking at its performance during the Great Recession, attention now switches to the fiscal policy alternatives after September 2014. Absent a fiscal policy response, one would expect a smooth adjustment path of macroeconomic variables back to trend. When the policy instrument is the labor income tax, the paths for macroeconomic variables come closest to this hypothetical smooth adjustment path. The model calls for a 9.4 percentage point increase in the labor income tax in the first year of fiscal austerity, and the macroeconomic disruptions are mild. When the policy instrument is the consumption tax, the increase in the tax rate is quite similar at 9.7 percentage points. The key difference relative to the labor income tax is a sharp and persistent decline in investment. Under all of the tax-based policies, government spending returns immediately to trend. In contrast, when public spending is the policy instrument, government expenditures immediately plummet to $28 \%$ below trend, a drop of $23 \%$. To smooth utility, households respond by raising private spending and investment. Since households foresee the large increase in the capital income tax rate when it is the policy instrument (a 31.4 percentage point increase), the path for capital is quite a bit below the paths associated with the other policy instruments throughout the Great Recession and beyond. Yet, there is relatively little effect on macroeconomic variables when the policy rule actually becomes operational after the Great Recession. For the most part, the paths of labor market variables are remarkably similar under the four policy instruments: There are small, brief differences, lasting roughly a year, after the Great Recession. By way of example, the largest difference between the 
unemployment rate paths is 0.5 percentage points. Taken at face value, these results suggest that fiscal policy has little effect, either directly or indirectly, on developments in the labor market.

A couple of alternative model simulations shed light on the importance of specific model features. First up is a model with Walrasian labor markets so that the model resembles that typically used in the business cycle literature. Using an empirically plausible labor supply elasticity $(1 / 4)$, the model predicts a much smaller decline in employment during the Great Recession than the benchmark model. Consequently, replicating the path of U.S. output requires much larger variation in total factor productivity than in the search-and-matching model. Of course, this employment response could be augmented by increasing the labor supply elasticity. Regardless of the value of this elasticity, the subsequent employment response to fiscal policy seems implausibly large. Specifically, when either the labor income tax or the consumption tax is the policy instrument, employment ends up farther below trend than it was during the Great Recession.

The second alternative simulation is motivated by claims that the Beveridge curve, the empirical relationship between vacancies and unemployment, shifted during the Great Recession; see Diamond and Şahin (2014), Hobijn and Şahin (2013). To capture this possibility, choose a path for match efficiency to fit the path for the job-finding probability, keeping the cost of a vacancy constant. Doing so requires a severe decline in match efficiency, from well above 0.6 in 2007 to less than 0.3 in 2009. Such a decline in match efficiency is associated with a similar decline in the probability that a vacancy matches with a worker. By way of contrast, the benchmark model (the one that chooses a path for the cost of a vacancy) sees a rise in this worker-finding probability. Since this probability is inversely related to the average duration of a vacancy (how long it takes to fill a vacancy), the benchmark model implies a drop in the average duration of a vacancy while the match efficiency model sees a rise. The empirical evidence favors the benchmark model: Davis, Faberman, and Haltiwanger (2013) 
find that during the Great Recession, the average duration of a vacancy fell by nearly a half. ${ }^{2}$

The welfare consequences of using different policy instruments are evaluated in Section 5.3. Let the baseline policy be the one that selects public spending as the policy instrument. The welfare benefit of switching to a tax instrument is measured by a Hicksian equivalent variation payment that makes households indifferent between the baseline policy and the proposed tax instrument. Switching from government spending to the labor income tax leads to a sizable welfare loss, the bulk of which can be attributed directly to the loss in income due to the tax increase itself. In contrast, switching to either of the other two taxes yields welfare gains, with the larger gain being associated with the capital income tax. In these latter two cases, it is the induced variation in the intertemporal marginal rate of substitution for private goods (which captures the effects of discounting) that accounts for most of the welfare gains. Of course, households do not particularly like being taxed more heavily. Rather, they face a trade-off: under the government spending policy, public expenditures immediately and significantly decline, leading to a loss in utility that is only partly offset by higher private consumption. In contrast, tax-based policies see an immediate rise in public spending back to trend. So, while the tax hikes are associated with larger distortions, they are also accompanied by more public spending which households value. In the cases of the consumption and capital income taxes, the trade-off works in favor of switching to a tax-based debt reduction.

The welfare results are somewhat sensitive to an aspect of the benchmark calibration, namely a preference parameter that governs the intratemporal marginal rate of substitution between private and public consumption goods. The benchmark model chooses this parameter to equate, in steady state, the marginal utilities of these two goods - a choice motivated by the observation that it is the one that would be made by a benevolent planner. Calibrating instead so that the marginal utility of private goods exceeds that of public goods makes the trade-off between private and public goods less favorable towards using a tax rate rather than government spending as the fiscal policy instrument. That said, households would have to

\footnotetext{
${ }^{2}$ Data for Davis, Faberman, and Haltiwanger (2013) was downloaded from http://dhihiringindicators.com/.
} 
value, on the margin, private consumption goods much more than public goods to overturn the results of the benchmark model favoring a switch from using government spending as the policy instrument to either the consumption tax or the capital income tax.

Since the paper considers the effects of fiscal consolidation conditional on the current economic situation resulting from the Great Recession, it bridges two strands of the literature: one concerning the causes and effects of the Great Recession, the other on fiscal consolidation. Within the first set, Christiano, Eichenbaum, and Trabandt (2015) shed light on the factors driving the dynamics of output, inflation and the labor market during the Great Recession using a medium-scale model with endogenous labor force participation. They argue that a combination of financial, total factor productivity and cost of working capital shocks can account for most of the dynamics of the U.S. economy during the Great Recession. We consider a smaller model, and abstract from financial frictions and the zero lower bound on nominal interest rates, but embed a much more detailed representation of the labor market and a richer set of fiscal policy variables, including public debt.

Elsby, Hobijn, Sahin, and Valletta (2011) and Elsby, Hobijn, and Şahin (2010) characterize the dynamics of the labor market since 2008 and show that flows from nonparticipation to unemployment are important for understanding recent changes in the duration distribution of unemployment. Our model of the labor market is more conventional in abstracting from flows in and out of the labor force, but is still able to capture the bulk of labor market dynamics quite accurately. Sala, Söderstrom, and Trigari (2012) use an estimated DSGE model with search and matching frictions and show that match efficiency (along with financial factors) explain most of the rise of the unemployment rate in the U.S. after 2008. Furlanetto and Groshenny (2013) present similar results. Our analysis highlights the fact that the cost of vacancies, rather than match efficiency, is crucial in accounting for the dynamics of labor markets during the Great Recession. In fact, when our model is solved with a constant vacancy cost, choosing instead a time path for match efficiency, the model predicts that the average duration of a vacancy rises during the Great Recession whereas the facts point to a 
fall; see Section 5.4.2.

On the fiscal consolidation side, Mendoza, Tesar, and Zhang (2013) run debt sustainability experiments in the Euro Area while Auray, Eyquem, and Gomme (forthcoming) run debtoutput ratio reduction experiments, again in Euro Area countries. Erceg and Linde (2013) run comparable experiments with a particular focus on the role of the zero lower bound on nominal interest rates, nominal rigidities and an interaction between fiscal and monetary policy. Corsetti, Kuester, Meier, and Müller (2010) show that expectations matter for the size of the effects of fiscal consolidations. Our paper is more focused on the joint analysis of fiscal consolidations and labor market dynamics. Closest to our paper is Nukic (2014) who quantifies the output and employment losses induced by "unconditional" fiscal consolidations in a framework that embeds search and matching frictions in the labor market. However Nukic does not consider the capital income tax as an instrument, and assumes that the economy is in steady state before fiscal consolidation is implemented. We solve our model non-linearly which is particularly important since at the start of the period of fiscal austerity, the economy is not in a steady state. Further, it is well known that nonlinear solutions are important in evaluating the welfare consequences of alternative policies.

The remainder of the paper is organized as follows. Section 2 looks at U.S. data during and after the Great Recession. The model is presented in Section 3 and calibrated in Section 4. Model results, policy analysis and robustness results are contained in Section 5. Section 6 concludes.

\section{The Great Recession}

Figure 1 presents a number of facts concerning the behavior of macroeconomic variables during the Great Recession. The quarterly data in Figures 1(a) to 1(d) are detrended by applying the Hodrick-Prescott with a high smoothing parameter, $\lambda=100,000$, in order to remove the trend, but to prevent the filter from absorbing too much of the downturn. Output, 
depicted in Figure 1(a), fell precipitously from nearly $3 \%$ above trend, to $3.7 \%$ below trend over the course of roughly a year-and-a-half. This fall in output was very long lived, and it is only late in 2014 that it recovers to trend. ${ }^{3}$ It should be noted, though, that the persistent drop in output ends up pulling the trend line down, and so this recovery to trend is partly due to a lower trend. While the NBER business cycle dating committee set the end of the Great Recession in mid-2009, we consider the Great Recession to run from the business cycle peak in December 2007 through to September 2014 when output returned to trend.

The falls in consumption and investment, in Figures 1(b) and 1(c), are likewise large particularly for investment which, by the end of the Great Recession, was more than $30 \%$ below trend. While consumption has yet to recover to trend, by early 2013 investment had risen above trend.

Figures 1(d) to 1(f) tell the story of the fiscal side of the economy. Government spending rose from $1.6 \%$ above trend just prior to the Great Recession to $5.6 \%$ at the trough. Indeed, government spending remained more than 5\% above trend through to mid-2010, after which there was a fairly sharp drop. By early 2012, government spending had fallen below trend, and was more than $5 \%$ below trend through all of 2014. Budget deficits largely follow the pattern of government spending, rising from $0.3 \%$ of GDP just prior to the Great Recession, to $3.2 \%$ in early 2010 , after which this ratio has fallen somewhat. As a consequence of those larger deficits, the government debt-output ratio rose from $59 \%$ prior to the Great Recession to $103 \%$ in late 2014.

While it is widely accepted that the proximate cause of the Great Recession was the financial crisis, the depth and persistence of the Great Recession is largely a story of the labor market. Figure 2(c) shows that the unemployment rate rose from somewhat less than $5 \%$ just prior to the Great Recession, to a peak of $10 \%$ in late 2009, nearly a full year after the trough. While the unemployment rate has fairly steadily fallen since then, it has remained stubbornly high. These movements in the unemployment rate can usefully be traced to changes in the

\footnotetext{
${ }^{3}$ The Hodrick-Prescott filter in $\mathrm{R}$ does not restrict the trend line to pass through the first and last observations in a time series, so this recovery to trend is not an artifact of the Hodrick-Prescott filter.
} 
Figure 1: Great Recession Facts: Macroeconomic Variables

(a) Output

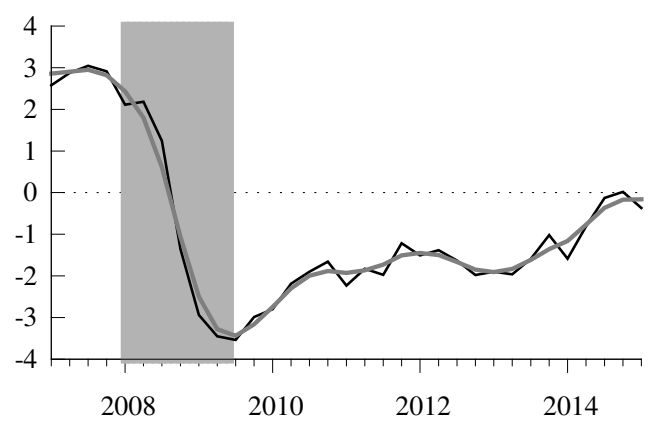

(c) Investment

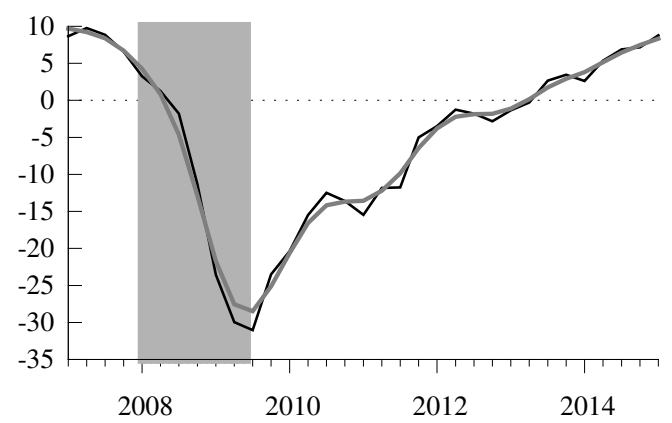

(e) Government budget surplus (\% output)

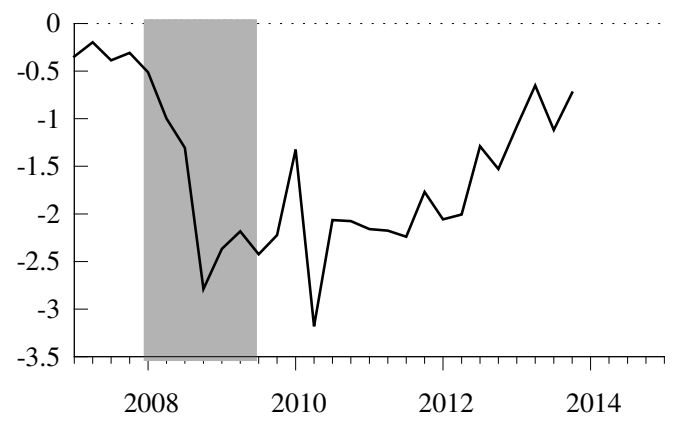

(b) Consumption

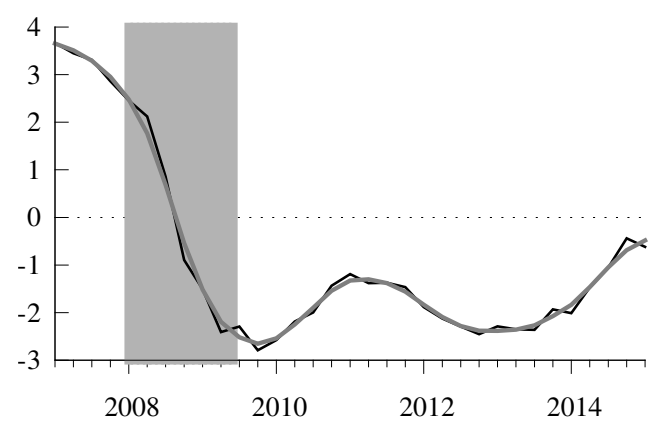

(d) Government spending

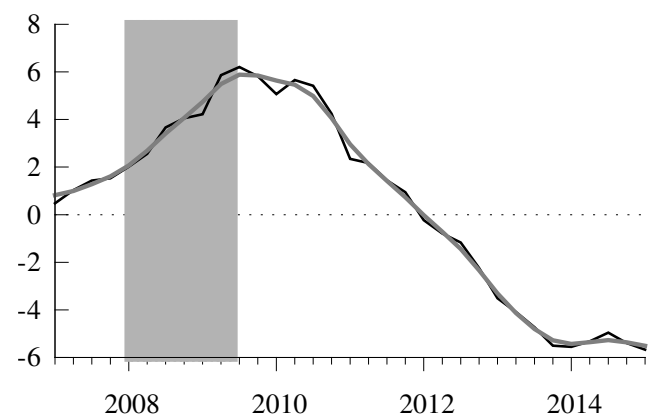

(f) Government debt (\% output)

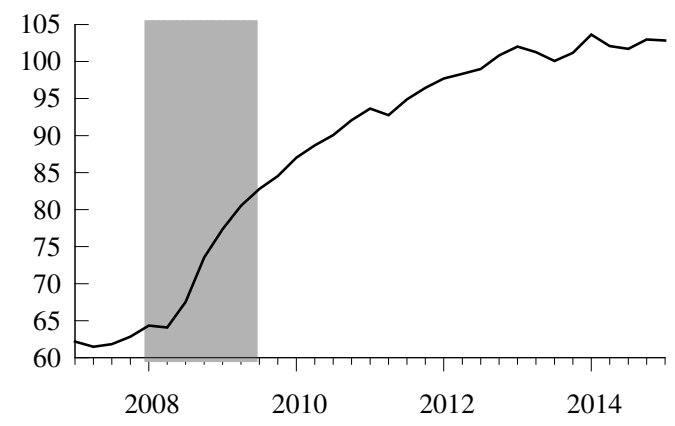

Note: The shaded area corresponds to the NBER definition of the Great Recession, that is from peak to trough. 
Figure 2: Great Recession Facts: The Labor Market

(a) Separation probability (\%)

(b) Job-finding probability (\%)

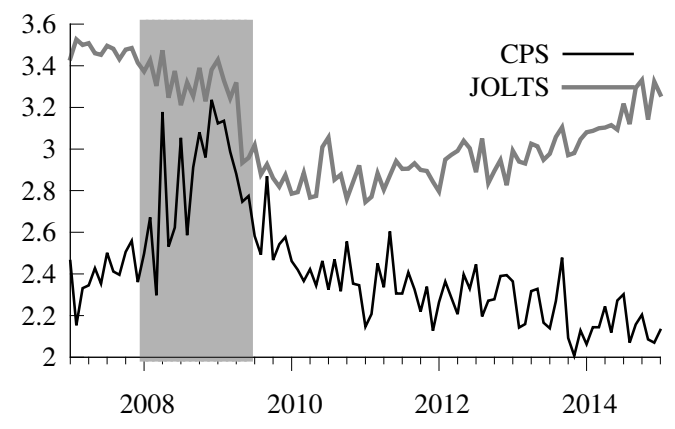

(c) Unemployment rate $(\%)$

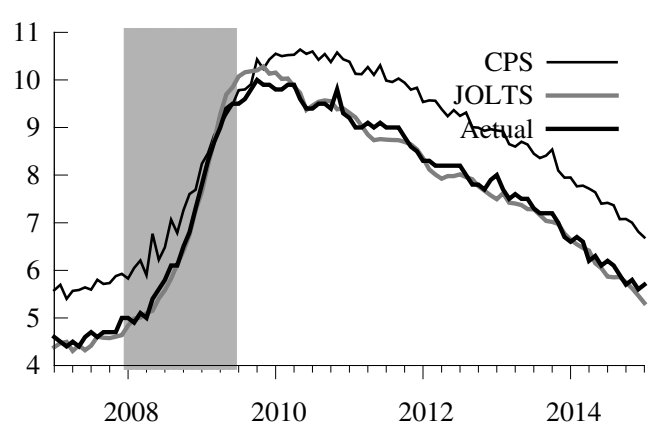

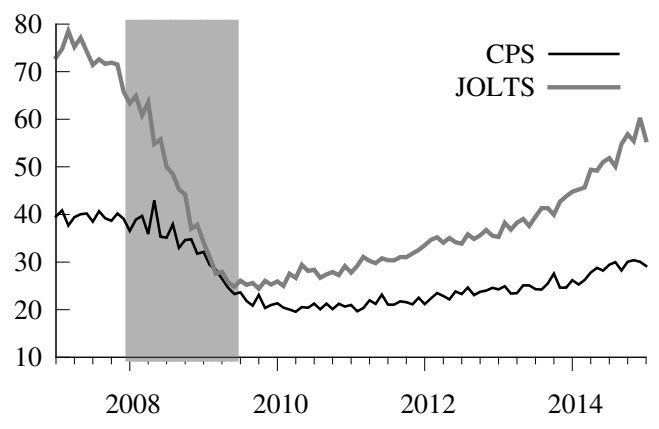

(d) Vacancies

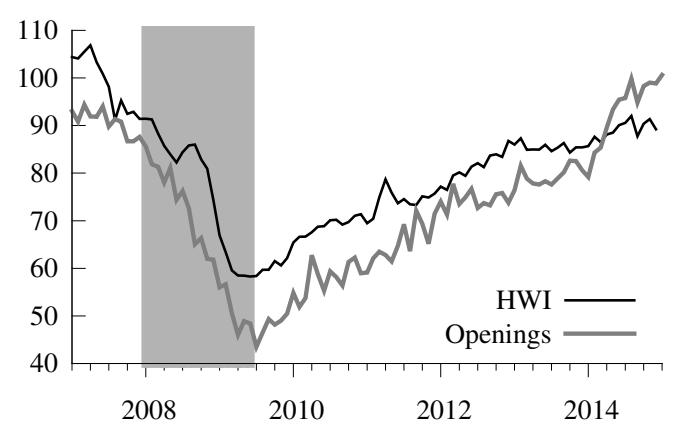

Note: The shaded area corresponds to the NBER definition of the Great Recession, that is from peak to trough. Job openings from JOLTS is normalized to equal 100.0 in December 2000 . 
job-finding $\left(f_{t}\right)$ and separation probabilities $\left(s_{t}\right)$. Abstracting from movements in and out of the labor force, the stock of employment evolves according to

$$
e_{t+1}=\left(1-s_{t}\right) e_{t}+f_{t} u_{t}
$$

where $e_{t}$ is the number of employed workers, and $u_{t}$ the number unemployed. One well-known approach to imputing these probabilities is that proposed by Shimer (2005). Not only is the number of unemployed reported for the U.S., so is the number of short term unemployed (less than 5 weeks), $u_{t}^{s}$. Using this methodology, the job-finding probability is given by

$$
f_{t}=-\ln \left(\frac{u_{t}-u_{t}^{s}}{u_{t-1}}\right)
$$

The separation probability, then, is given by the nonlinear solution to

$$
u_{t+1}=\left(1-\exp \left(-f_{t}-s_{t}\right)\right) \frac{\left(u_{t}+e_{t}\right) s_{t}}{f_{t}+s_{t}}+\exp \left(-f_{t}-s_{t}\right) u_{t}
$$

see Shimer for details on the derivation of this formula. The probabilities $f_{t}$ and $s_{t}$ are plotted in Figures 2(a) and 2(b), labeled 'CPS' since they are based on Current Population Survey data. According to these series, the sharp rise in the unemployment rate is largely due to a rise in the probability of losing a job which rises from roughly $2.4 \%$ per month in the year prior to the Great Recession, to well over 3\% during the recession. This probability has, since, returned to around its pre-recession value. Meanwhile, during the Great Recession, the job-finding probability fell from around $40 \%$ to roughly half that, around $20 \%$. The slow fall in the unemployment rate is, then, attributable to the fact that the job-finding probability has yet to return to its pre-recession level.

More recently, the JOLTS (Job Openings and Labor Turnover Survey) gives more direct measures of job separations and hiring. Measure the JOLTS-based job-finding probability by the number of hires divided by the number unemployed, and the separation probability by separations divided by employment. ${ }^{4}$ These probabilities are similarly depicted in Figures 2(a)

\footnotetext{
${ }^{4}$ Employment and unemployment are taken from the CPS data.
} 
and 2(b), in this case labeled 'JOLTS'. According to the JOLTS data, the probability of separating from a job prior to the Great Recession was much higher than the CPS data suggests: over $3.2 \%$ per month compared to $2.4 \%$ per month. Between the peak and the trough of the Great Recession, the JOLTS-based separation probability actually fell, and since the trough was as low as $2.6 \%$ per month. Meanwhile, according to the JOLTS data, prior to the Great Recession, the job-finding probability was quite high at nearly $70 \%$ (compared to $40 \%$ for the CPS-based measure). This probability then fell precipitously to the mid-20s around the trough; since then, the job-finding probability gradually rose. Thus, the JOLTS data suggest that the behavior of the unemployment rate during the Great Recession was largely driven by the pattern in the job-finding probability: the large rise in unemployment early in the Great Recession was because it became harder to find jobs; the persistence in the unemployment rate is likewise due to difficulties the unemployed had in finding jobs.

Clearly, the two measures of the job-finding and separation probabilities give very different interpretations of the labor market during the Great Recession and its aftermath. Which of the two comes closest to the 'truth'? One way to choose between them is to use the job-finding and separation probabilities to infer a time series for the unemployment rate. Starting with the unemployment rate in January 2007, compute inferred unemployment rates using

$$
\tilde{u}_{t+1}=\left(1-f_{t}\right) \tilde{u}_{t}+s_{t}\left(1-\tilde{u}_{t}\right),
$$

where $\tilde{u}_{t}$ is the unemployment rate (and so $1-\tilde{u}_{t}$ is the employment rate). These fitted series, along with the actual unemployment rate, are plotted in Figure 2(c). Visually, it can be seen that the JOLTS-based probabilities deliver fitted unemployment rates that are much closer to actual than the CPS-based probabilities. The CPS-based measure of unemployment exceeds actual through 2007 and 2008, and after 2010; these differences are roughly one percentage point. While the JOLTS-based fitted unemployment rate peaks a bit higher than actual, it generally follows the actual unemployment rate fairly closely. Consequently, below we will focus on the JOLTS-based measures of the job-finding and separation probabilities. 


\section{The Model}

In order to maintain the representative agent fiction, private agents are modeled as belonging to a large family. This family values both private and government consumption, the latter being taken as exogenous by the family. The family's problem is broken into a number of parts. Taking as given wage and employment determination, the family decides on its private consumption as well as accumulation of assets in the form of both physical capital and holdings of government debt. After presenting this part of the household's problem, the analysis proceeds to the determination of wages and employment.

\subsection{The Family}

Households value a private good, $c_{t}$, and a government good, $g_{t} \cdot{ }^{5}$ Preferences over these goods are summarized by

$$
\sum_{t=0}^{\infty} \beta^{t} U\left(c_{t}, g_{t}\right), \quad 0<\beta<1 .
$$

The household pays a tax, $\tau_{c t}$, on its consumption purchases as well as taxes on its labor income, $\tau_{w t}$, and capital income, $\tau_{k t}$. Capital income taxes payable are partially offset by a capital consumption allowance. Capital adjustment costs,

$$
\Phi_{t}=\frac{\phi}{2}\left(k_{t+1}-k_{t}\right)^{2}
$$

are included so that the dynamics of investment better fit the data during the Great Recession. The household's share of distributed profits is $\pi_{t}$. Households also purchase one period government debt, $d_{t+1}$, with this debt sold as a discount, $p_{t}$. Finally, households also receive a lump-sum transfer, $T$. Letting $e_{t}$ denote the fraction of household members gainfully employed, and $u_{t}$ be the fraction collecting unemployment (with $e_{t}+u_{t}=1$ ), the household's

\footnotetext{
${ }^{5} \mathrm{As}$ is common in the search-and-matching literature, the role or leisure or participation is suppressed.
} 
date $t$ budget constraint is

$$
\left(1+\tau_{c t}\right) c_{t}+k_{t+1}+\Phi_{t}+p_{t} d_{t+1}=\left(1-\tau_{w t}\right)\left(w_{t} e_{t}+b_{t} u_{t}\right)+\left[1+\left(1-\tau_{k t}\right)\left(r_{t}-\delta\right)\right] k_{t}+d_{t}+\pi_{t}+T .
$$

Taking as given for the moment the determination of wages and employment (and so unemployment), the household's Euler equations for capital and bond accumulation are

$$
\begin{gathered}
1+\phi\left(k_{t+1}-k_{t}\right)=\Delta_{t, t+1}\left[1+\phi\left(k_{t+2}-k_{t+1}\right)+\left(1-\tau_{k, t+1}\right)\left(r_{t+1}-\delta\right)\right], \\
p_{t}=\Delta_{t, t+1},
\end{gathered}
$$

where

$$
\Delta_{t, t+1}=\beta \frac{U_{1}\left(c_{t+1}, g_{t+1}\right)}{1+\tau_{c, t+1}} / \frac{U_{1}\left(c_{t}, g_{t}\right)}{1+\tau_{c t}}
$$

is the household's effective discount factor between date $t$ and $t+1$.

\subsection{Workers and the Unemployed}

Within the family, individuals account for their marginal contributions to private, family consumption. The value of being employed is given by

$$
W_{t}=\left(1-\tau_{w t}\right) w_{t}+\Delta_{t, t+1}\left[\left(1-s_{t}\right) W_{t+1}+s_{t} U_{t+1}\right]
$$

where $s_{t}$ is the exogenous separation probability. Separations occur at the end of a period, after production has taken place. An individual then spends at least one period unemployed since matching occurs at the end of a period. The first term on the right-hand side is the after-tax wage, representing the current contribution to family consumption. The second term represents the expected present value over future employment statuses: with probability $1-s_{t}$, the individual remains employed and the capital value of remaining employed is $W_{t+1}$; and with probability $s_{t}$, the individual loses his job and enters the pool of unemployed which has capital value $U_{t+1}$. The discount factor, $\Delta_{t, t+1}$, takes care of converting these future values into units of current consumption goods. 
Similarly, the value of searching (that is, unemployed) is

$$
U_{t}=\left(1-\tau_{w t}\right) b_{t}+\Delta_{t, t+1}\left[\left(1-f_{t}\right) U_{t+1}+f_{t} W_{t+1}\right]
$$

where $f_{t}$ is the probability of being matched with a firm at the end of the current period. On the right-hand side, the first term is the after-tax unemployment insurance benefit; the other term is the expected value of search.

\subsection{Firms}

Firms act in the best interests of their owners, namely the representative household. Unlike the usual Mortensen-Pissarides model, a firm is modeled as a collection of jobs and rents capital to produce goods. ${ }^{6}$ The value of the marginal worker is

$$
J_{t}=F_{2}\left(k_{t}, e_{t} ; z_{t}\right)-w_{t}+\Delta_{t, t+1}\left[\left(1-s_{t}\right) J_{t+1}+s_{t} V_{t+1}\right],
$$

where $V_{t+1}$ is the value of the position remaining vacant. The term $F_{2}\left(k_{t}, e_{t} ; z_{t}\right)-w_{t}$ is the net contribution of the marginal worker, his marginal product less his wage. The last term in Eq. (8) is the expected value of the match into next period. Notice that the firm applies the same effective discount factor, $\Delta_{t, t+1}$, as was used by employed and unemployed family members.

The value of a vacant position is

$$
V_{t}=-\kappa_{t}+\Delta_{t, t+1}\left[a_{t} J_{t+1}+\left(1-a_{t}\right) V_{t+1}\right]
$$

where $\kappa_{t}$ is the per period cost of posting a vacancy, and $a_{t}$ is the probability that a vacancy is matched with an unemployed worker. As usual in the Mortensen-Pissarides model, there is free entry with respect to vacancies which drives the equilibrium value of a vacancy to zero. This condition implicitly determines the equilibrium number of vacancies posted, $v_{t}$.

\footnotetext{
${ }^{6}$ In the usual formulation of the Mortensen-Pissarides model, a firm is a job. Left unspecified is how a vacant firm/job finances the cost of posting a vacancy. An advantage of specifying that a firm is a collection of jobs is that the cost of vacancies is financed by the firm's current revenues.
} 
Firms rent capital from households on a spot market. Consequently, firms will hire capital up to the point that the marginal product of capital equals its rental rate, or

$$
F_{1}\left(k_{t}, e_{t} ; z_{t}\right)=r_{t}
$$

Finally, firm profits are given by

$$
\pi_{t}=F\left(k_{t}, e_{t} ; z_{t}\right)-w_{t} e_{t}-r_{t} k_{t}-v_{t} \kappa_{t} .
$$

\subsection{Wage Determination}

Wages are determined as the solution to Nash bargaining which maximizes the geometric average of worker and firm surpluses,

$$
w_{t}=\operatorname{argmax}\left(W_{t}-U_{t}\right)^{\theta}\left(J_{t}-V_{t}\right)^{1-\theta} .
$$

where $\theta$ measures the worker's 'bargaining power' in the match. Using Eqs. (6)-(7) along with the free-entry condition (which implies $V_{t}=0$ ), wages are implicitly given by the first-order condition,

$$
(1-\theta)\left(W_{t}-U_{t}\right)=\theta\left(1-\tau_{w t}\right) J_{t}
$$

It is assumed that wages are renegotiated every period, and so $w_{t}$ is the wage that will prevail in all matches.

\subsection{Evolution of Employment}

The behavior of employment over time is governed by

$$
e_{t+1}=\left(1-s_{t}\right) e_{t}+m_{t} \text { where } m_{t}=M\left(v_{t}, u_{t}\right) \text {. }
$$


The matching function, $M$, is constant returns to scale and has positive first derivatives. Given the matching function, the job-finding probability is

$$
f_{t}=\frac{m_{t}}{u_{t}}=M\left(\frac{v_{t}}{u_{t}}, 1\right)
$$

while the probability that a vacancy matches with a worker is

$$
a_{t}=\frac{m_{t}}{v_{t}}=M\left(1, \frac{u_{t}}{v_{t}}\right) .
$$

\subsection{Government}

Government debt evolves according to

$$
p_{t} d_{t+1}-d_{t}=\operatorname{def}_{t},
$$

where the primary deficit is

$$
\operatorname{def}_{t}=g_{t}+T+\left(1-\tau_{w t}\right) b_{t} u_{t}-\tau_{c t} c_{t}-\tau_{w t} w_{t} e_{t}-\left(\tau_{k t}-\delta\right) r_{t} k_{t} .
$$

The first two terms on the right-hand side of Eq. (18) are government spending on goods and services, $g_{t}$, and a lump-sum transfer, $T$. The next term represents the government's expenditures on unemployment insurance, net of tax. The final terms are government tax revenue from the consumption tax, labor income, and capital income (net of the depreciation allowance).

It is well known that, absent any feedback, the debt dynamics in Eqs. (17) and (18) are inherently unstable. We impose the fiscal policy rule

$$
\frac{\operatorname{def}_{t}}{y_{t}}-\frac{\text { def }}{y}=-\omega\left[\frac{d_{t}}{y_{t-1}}-\frac{d}{y}\right], \quad \omega>0 .
$$

The government chooses one of its fiscal policy instruments (spending or one of the tax rates) to satisfy this rule. In Eq. (19), $d / y$ is the target for the debt-output ratio and def/y is the corresponding value for the primary deficit-output ratio. Eq. (19) says that when the 
government debt-output ratio is above target, the government must apply austerity measures (higher taxes or lower government spending) in order to reduce the primary deficit. It is this feedback mechanism that renders the debt-output ratio stationary.

\subsection{Equilibrium}

In brief,

1. Households optimize.

2. Firms optimize.

3. The government satisfies its budget constraints.

4. Markets clear.

\section{Calibration}

A model period is set to one month, shorter than the typically-used quarter in macroeconomics. The monthly frequency is chosen so that the model can match the observed duration of U.S. unemployment spells which is considerably shorter than a quarter: prior to the Great Recession, Figure 2(b) shows that the monthly job-finding probability was roughly $40 \%$ (CPS data) or $70 \%$ (JOLTS data). These job-finding probabilities imply an average duration of unemployment of either 2.5 months (CPS), or 1.4 months (JOLTS).

The utility function is of the constant relative risk aversion variety:

$$
U(c, g, u)= \begin{cases}\ln C(c, g) & \gamma=1 \\ \frac{C(c, g)^{1-\gamma}}{1-\gamma} & \gamma \in(0,1) \cup(1, \infty) .\end{cases}
$$

The consumption aggregator is

$$
C(c, g)=\left[\psi c^{\frac{\xi-1}{\xi}}+(1-\psi) g^{\frac{\xi-1}{\xi}}\right]^{\frac{\xi}{\xi-1}}
$$


where $\xi$ is the elasticity of substitution between private and government goods.

As is common in the Mortensen-Pissarides literature, the matching function is CobbDouglas:

$$
M(v, u ; \mu)=\mu v^{\nu} u^{1-\nu}
$$

Finally, production is Cobb-Douglas:

$$
y=F(k, h ; z)=z k^{\alpha} h^{1-\alpha}
$$

\begin{tabular}{|c|c|c|}
\hline \multicolumn{3}{|c|}{ Preferences } \\
\hline$\beta$ & Discount factor & 0.9967 \\
\hline$\gamma$ & Coefficient of relative risk aversion & 2 \\
\hline$\xi$ & Consumption aggregator elasticity of substitution & 2 \\
\hline$\psi$ & Consumption aggregator weight on private consumption & 0.6326 \\
\hline \multicolumn{3}{|c|}{ Production } \\
\hline$\alpha$ & Elasticity of output with respect to capital & 0.3 \\
\hline$\delta$ & Depreciation rate & 0.0059 \\
\hline$z$ & Steady state total factor productivity & 1 \\
\hline$\phi$ & Capital adjustment cost & 0.75 \\
\hline \multicolumn{3}{|c|}{ Matching and Bargaining } \\
\hline$\mu$ & Match efficiency & 0.61 \\
\hline$\nu$ & Elasticity of matches with respect to vacancies & 0.7 \\
\hline$\theta$ & Workers' bargaining power & 0.3 \\
\hline$\kappa$ & Steady state vacancy cost & 4.1290 \\
\hline \multicolumn{3}{|c|}{ Fiscal Policy } \\
\hline & Consumption tax rate & $6.5 \%$ \\
\hline & Labor income tax rate & $30.12 \%$ \\
\hline$\tau_{k}$ & Capital income tax rate & $49.77 \%$ \\
\hline & Feed back parameter, government policy rule & 0.15 \\
\hline & Lump-sum tax & 0.2915 \\
\hline
\end{tabular}

Table 1: Benchmark Parameters

As summarized in Table 1, there are 17 model parameters that must be assigned values. To start, some values are set exogenously. The coefficient of relative risk aversion, $\gamma$, is set to 2 , a value within the range typically used in business cycle models. The elasticity parameter $\xi$ in the consumption aggregator is also set to 2 which implies that private and public consumption are fairly easily substituted; the implications of smaller values of $\xi$ are 
explored in Section 5.4. The workers' bargaining parameter, $\theta$, is set to $1-\nu$ where $\nu$ is the elasticity of matches with respect to vacancies; this setting is motivated by the so-called Hosios condition which ensures constrained efficiency. Steady state total factor productivity, $z$, is normalized to equal 1. The fiscal policy feedback parameter, $\omega$, is set to $0.15{ }^{7}$ Sensitivity with respect to this parameter is reported in Section 5.4. The final exogenously-set parameter is $\phi$ which governs the capital adjustment costs; it is set to $3 / 4$ in order to roughly match the observed decline in investment during the Great Recession.

There remain 12 parameters which are chosen to line up with the following targets: an annual depreciation rate of $7.8 \%$ as reported in Gomme and Rupert (2007); an annual real interest rate of $4 \%$, a conventional value; an elasticity of matches with respect to vacancies of 0.7, a value at the top of the range estimated by Petrongolo and Pissarides (2001); the tax rates, $\tau_{w}, \tau_{c}$ and $\tau_{k}$ match those computed by Mendoza, Razin, and Tesar (1994); an elasticity of output with respect to capital of 0.3 , close to the value computed by Gomme and Rupert (2007); an average separation probability of 3.3\% per month, its average value based on JOLTS data between December 2001 and December 2007; a job-finding probability of 61\%, similarly computed from JOLTS data over the same period; the marginal utilities of private and public consumption are equalized (that is, $U_{1}=U_{2}$; alternative settings are explored below); the government budget must balance given a government share of output of $28.97 \%$ and an annual government debt-output ratio of 0.5907 , values which correspond to the situation in the U.S. just prior to the Great Recession; and the steady state vacancy-unemployment ratio is normalized to equal 1. The resulting parameter values can be found in Table 1.

Notice that the values for the separation probability and job-finding probability imply that the steady state unemployment rate is around 5.1\%, roughly its average value between 2002 and 2007. Next, the normalization that vacancies equal unemployment implies that the match efficiency parameter, $\mu$, equals both the job-finding and worker-finding probabilities, $f$ and $a$.

\footnotetext{
${ }^{7}$ The only evidence we have found regarding the policy feedback parameter, $\omega$, is Bohn (1998). He estimates values between 0.028 and 0.054. For our model, Bohn's largest estimate, 0.054, implies an implausibly slow return of the debt-output ratio to its target value.
} 
As a result, the model matches the job-finding probability. This value for the worker-finding probability seems reasonable. Its value implies an average duration of a vacancy of 1.6 months. According to Dice-DFW, just prior to the Great Recession, the average duration of a job vacancy was around 23 (working) days, or one calendar month. The model counterpart to the duration of a vacancy may be longer if there is a delay between when the firm recognizes that it has a job to fill and when it actually posts the vacancy, and if there is a lag between filling a vacancy and the worker's start date.

\subsection{Exogenous Processes}

Model simulations start in December 2002 so that the initial steady state does not influence the paths of variables leading up to the Great Recession. As discussed earlier, we consider the Great Recession period to continue until September 2014 when output finally returns to its trend path; see Figure 1(a). Over this period, December 2002 through to September 2014, the model is required to match U.S. data on the separation probability, the job-finding probability, output and government spending. The first two series are monthly; the latter two are spline-interpolated from quarterly to monthly. Output and government spending have been detrended by removing a very smooth trend line as described in Section 2. To see through short run fluctuations, quarterly time series have then been smoothed by taking the HP filter trend line with a smoothing parameter of 1 ; for monthly series, a smoothing parameter of $81 .^{8}$ The separation probability and government spending sequences are fed directly into the model. Solving the model involves finding series for the vacancy cost and total factor productivity over the Great Recession to match the job-finding probability and output series. We explore the implications of choosing a sequence for match efficiency instead of the cost of vacancies - in Section 5.4.

After the Great Recession (that is, starting in October 2014), the separation probability, vacancy cost and total factor productivity smoothly converge to their steady state values

\footnotetext{
${ }^{8}$ Given the annual smoothing parameter value of 1 , the monthly value of 81 is guided by considerations on adjusting the HP filter smoothing parameter discussed in Ravn and Uhlig (2002).
} 
described in Table 1 according to:

$$
\begin{gathered}
s_{t}=0.9 s_{t-1}+0.1 s, \\
\kappa_{t}=0.9 \kappa_{t-1}+0.1 \kappa \\
\ln z_{t}=\rho_{z} \ln z_{t-1}, \quad \rho_{z}=0.95^{1 / 3} .
\end{gathered}
$$

The autoregressive parameter for total factor productivity is the monthly analog of the value typically used for quarterly business cycle analysis. The autoregressive parameters for the separation probability and vacancy cost were chosen to match their rapid decline late in the Great Recession. For the final exogenous process, either government spending or one of the tax rates is chosen to satisfy the fiscal policy rule, Eq. (19). When a tax rate is chosen to satisfy the policy feedback rule, government spending immediately returns to trend.

Finally, so that the model ends up with a debt-output ratio close to 100\%, as observed in the data, after 2007 the lump-sum transfer is rapidly increased, up to a maximum of $40 \%$ above its steady state value. After 2014, it is then quickly brought back to steady state. Absent such a rise in the lump-sum transfer, the debt-output ends up just shy of $75 \%$. Getting this ratio roughly correct is important for the magnitude of the subsequent fiscal austerity that brings the debt-output ratio back to its pre-Great Recession value of 0.5907 .

The model is solved as a perfect foresight, two point boundary problem; see Auray, Eyquem, and Gomme (forthcoming) for a detailed description of the solution method. ${ }^{9}$

The initial and terminal conditions are the model's steady state. Since four alternative fiscal policies are considered, there are four paths for each variable of interest, one for each of the fiscal policy instruments, for the entire horizon over which the model is solved.

\footnotetext{
${ }^{9}$ Taking as given Eqs. (5), (10), (15), (16) and (18), the set of equations solved are: Eqs. (2)-(4), (6)-(9), (13), (14) and (17) along with $e_{t}+u_{t}=1$ and Eq. (19) after the Great Recession.
} 


\section{Results}

To better understand the strengths and weaknesses of the model, its performance over the Great Recession is analyzed first. The ability of the model to capture macroeconomic dynamics over the Great Recession lends credibility to the debt reduction policy analysis that follows.

\subsection{The Great Recession}

Recall that the model takes as given the job separation probability, and fits the job-finding probability. Almost by construction, the model does well in capturing the observed variation in the unemployment rate; compare the dynamics of the model in Figure 3(e) with the U.S. data in Figure 2(c). In particular, both the model and the data see a rise the unemployment rate from $4.5 \%$ prior to the Great Recession, to around $10 \%$ early in 2010; the unemployment rate then remains rather high for a considerable period of time.

To match the job-finding probability, the model requires nearly a $60 \%$ decline in vacancies; see Figure 3(b). In the data, vacancies as measured by Barnichon's (2010) help wanted index fell by around 40\% (from around 100.0 through 2007 to 58 or so in mid-2009). Alternatively, JOLTS sees a drop in job openings of about 50\% (from, say, 4500 in 2007 to 2200 in mid-2009). In other words, while the fall in vacancies as required by the model is larger than in the data, it is nonetheless in the right ball park. Given macroeconomic conditions, this drop in vacancies comes through roughly a four-fold increase in the cost of posting a vacancy; see Figure 3(a). One way to measure the reasonableness of such a large increase in the vacancy cost is to look at the worker-finding probability; the model predicts a rise in this probability from around $57 \%$ prior to the Great Recession to almost $90 \%$ at the end of 2009 . In other words, just after the trough, firms presumably found it quite easy to fill vacancies. This change in probabilities implies a fall in the average duration of a vacancy of $40 \%$ (from 1.75 months to 1.1 months). This percentage decline is close to that measured by Davis, 
Faberman, and Haltiwanger (2013) for the national mean vacancy duration, 35\% (from 23 working days to 15 working days).

Curiously, as shown in Figure 4(f), the model predicts a marked increase in real wages early in the Great Recession episode; real wages fall below trend only after the NBER-determined trough in mid-2009. What is going on is that the rapid rise in the vacancy cost increases the value of existing matches, and the Nash bargaining-determination of wages implies that workers receive their share of this increased surplus.

Given the employment dynamics, the model requires a $2.4 \%$ decline in total factor productivity in order to match the observed $6.2 \%$ fall in output; see Figures $3(\mathrm{~h})$ and $4(\mathrm{a})$. Interestingly, total factor productivity rises to nearly its pre-Great Recession level $(1.5 \%$ above trend) by mid-2010, remaining above trend until the end of the Great Recession period. Solow growth accounting reveals that the bulk of the drop in output (6.2\%) is accounted for by the fall in total factor productivity $(2.4 \%)$, and the contribution of the fall in employment ( $4.2 \%$ computed by the $6 \%$ decline in employment multiplied by the output elasticity with respect to employment, 0.7); very little of the fall in output is attributed to changes in the capital stock.

Recall that the capital adjustment cost parameter, $\phi$, was chosen to roughly match the observed downturn in investment (35\%). While actual investment started rising in mid-2009, passing above trend in mid-2014, the model predicts that investment stays well below trend throughout the Great Recession period; see Figures 1(c) and 4(c).

The model somewhat overstates the fall off in consumption; compare Figure 1(b) with Figure 4(b). Whereas the data shows a $6 \%$ drop, the model predicts just short of a $10 \%$ decline. In the model, some of the decline in consumption can be traced to households' responses to changes in government spending during the Great Recession. Specifically, in order to smooth utility, households offset the $5 \%$ rise in government spending by reducing their own consumption.

Turn now to fiscal policy during the Great Recession. Figure 4(g) shows a swing from a 
Figure 3: The Labor Market During and After the Great Recession

(a) Vacancy Cost

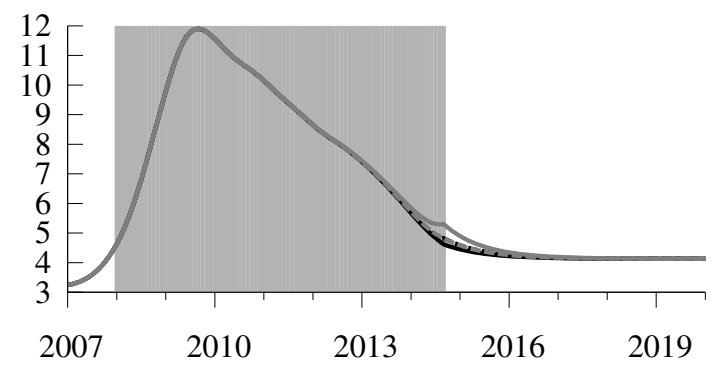

(c) Worker-finding Probability (\%)

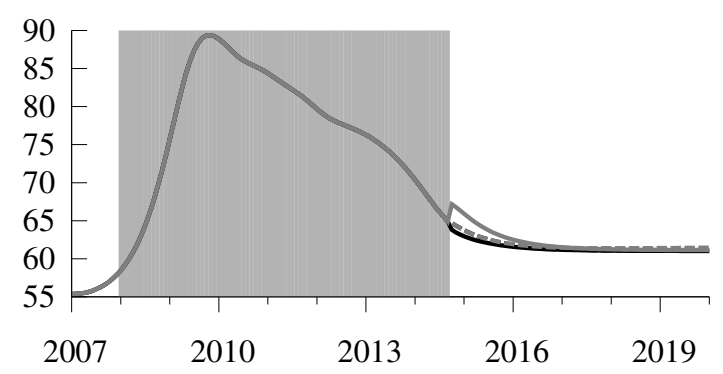

(e) Unemployment Rate (\%)

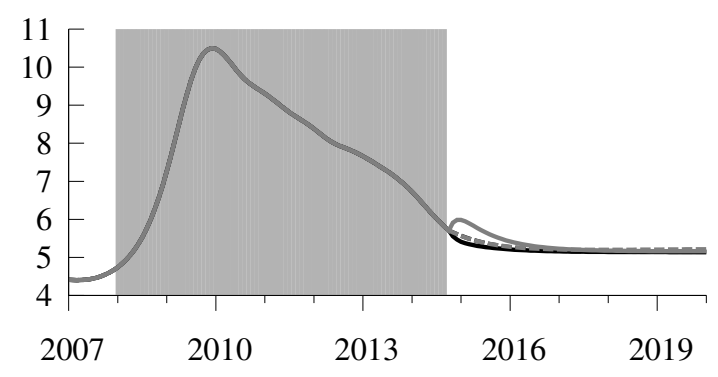

(g) Separation Probability (\%)

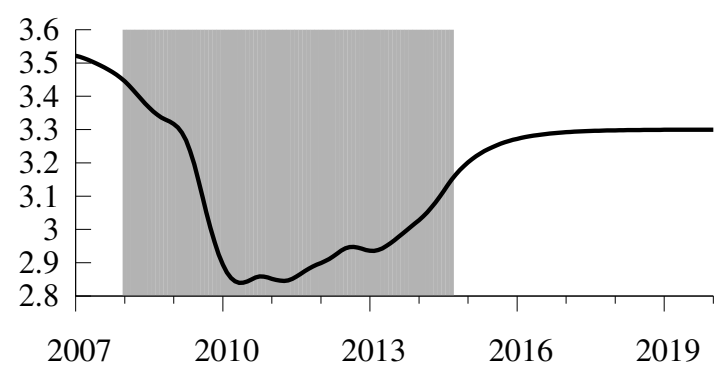

(b) Vacancies (\% deviation)

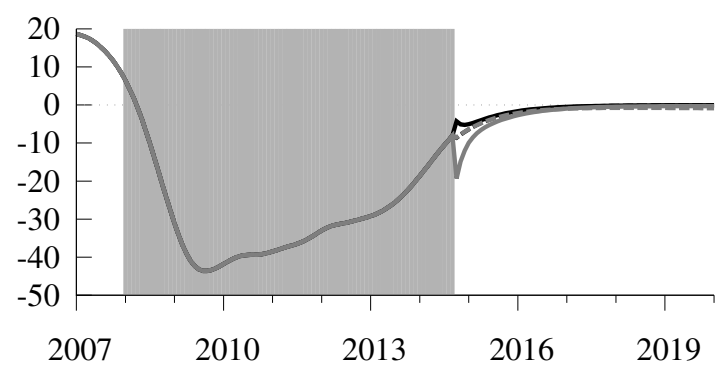

(d) Job-finding Probability (\%)

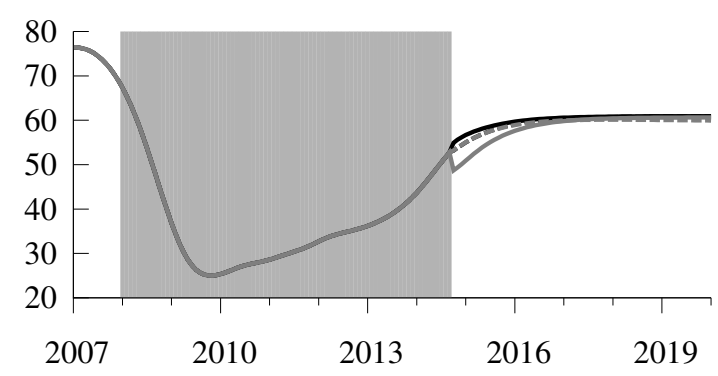

(f) Employment (\% deviation)

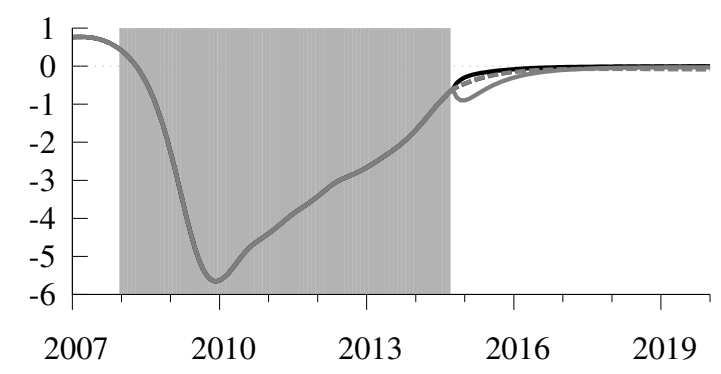

(h) Total Factor Productivity

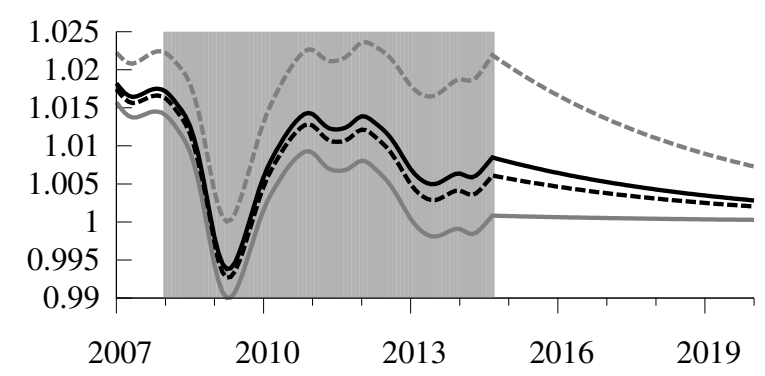

Legend: Solid black lines: government spending; dotted black lines: labor income tax; solid gray lines: consumption tax; dotted gray lines: capital income tax. The shaded area corresponds to the Great Recession period extended to mid-2014 when output returns to its balanced growth path. 


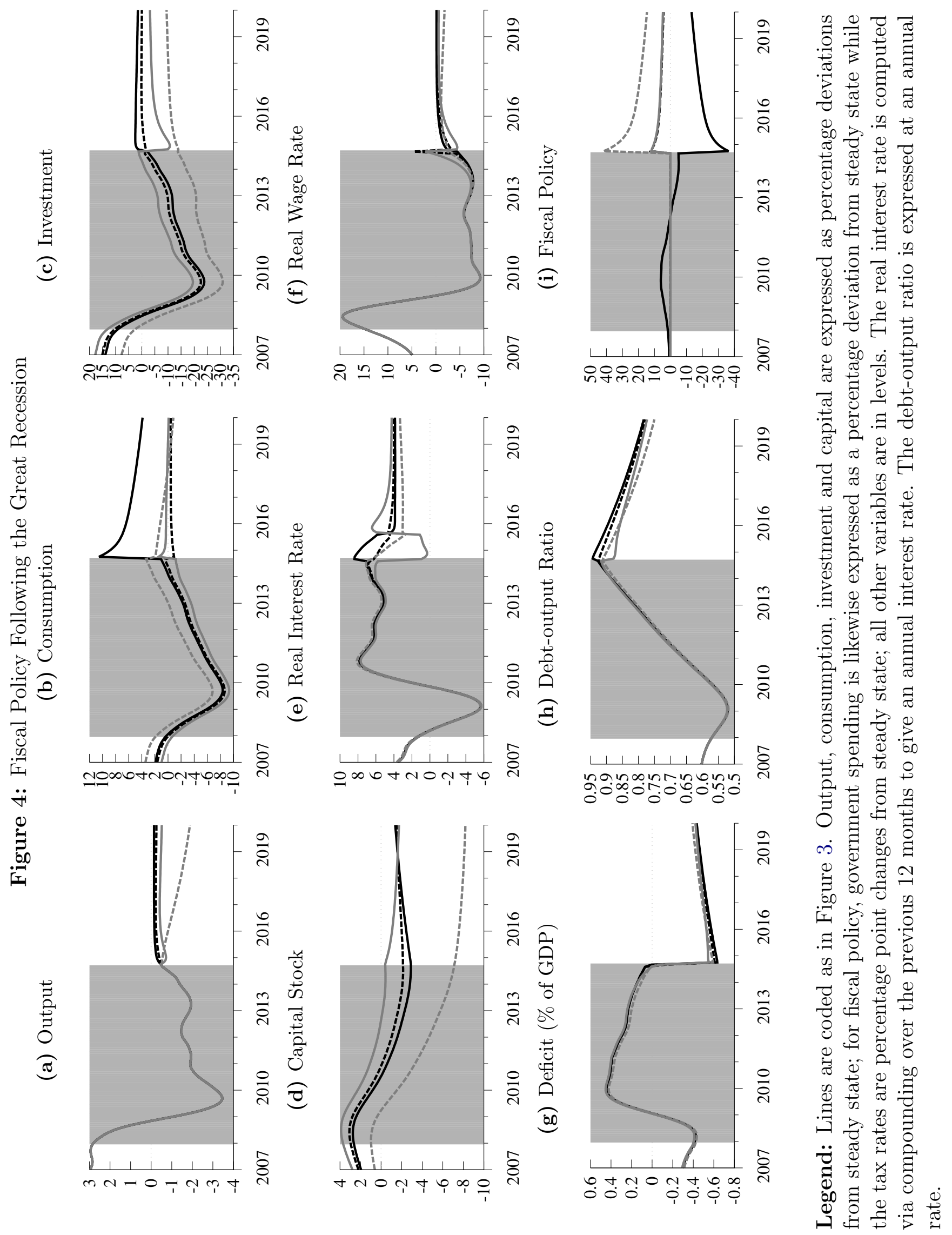


primary surplus to a primary deficit, driven by a combination of higher government spending, increased unemployment insurance payments, and diminished tax revenues arising from lower overall economic activity. The debt-output ratio actually falls early in the Great Recession. This peculiar result arises from an increase in the price of government debt, or equivalently a drop in the real interest rate, which makes it easier for government to finance its deficits. In fact, as shown in Figure 4(e), the real interest rate is quite negative in the early years of the Great Recession. Owing to a no arbitrage condition between the return on government debt and private capital, the decline in the real interest rate can be traced to a drop in the marginal product of capital resulting from a combination of lower total factor productivity and lower employment.

\subsection{Fiscal Policy after the Great Recession}

During the Great Recession, the paths for the variables of interest are sufficiently similar that it has not been necessary to distinguish between the scenarios associated with the four different fiscal policy instruments; that changes when looking post-Great Recession. An artifact of solving the model at a monthly frequency is that it generates paths for the fiscal variables that are also monthly. Yet, in the data, governments typically set tax rates for a year or more. To reconcile the model's monthly paths with observed government behavior, the changes in fiscal policy are reported by averaging over a year. ${ }^{10}$

To start, consider the model's predictions for the fiscal instruments themselves. Using government spending to bring down the debt-output ratio requires a $23 \%$ decline in the first year (bringing it from $5.0 \%$ below trend to $28 \%$ below). When the government instead uses a tax rate to satisfy its fiscal policy rule, it is assumed that government spending immediately returns to trend, implying a sizable increase in public consumption goods. Given that households desire to smooth the path for utility, this jump in public consumption goods has

\footnotetext{
${ }^{10}$ Qualitatively similar results are obtained by keeping fiscal instruments unchanged for 12 months at a time; the principle difference is that the discrete changes in the fiscal instruments lead to discrete jumps, every 12 months, in the other variables in the model.
} 
important implications for the path for private consumption. The hike in the labor income tax (9.4 percentage points) is quite close to that in the consumption tax (9.7percentage points). The capital income tax requires a much larger, 31.4 percentage point, increase. The differences in increases in the two factor income taxes can be traced to relative sizes of their tax bases. In particular, the tax base for the labor income tax is just over four times larger than that of the capital income tax. As a result, the percentage point increase in the capital income tax rate is a little over four times larger than that for the labor income tax. The consumption tax base is about $80 \%$ that of the labor income tax, but under the consumption tax the debt-output ratio falls more rapidly implying that smaller primary surpluses are needed under the consumption tax.

What is common across the four fiscal policy instrument is that the fiscal policy rule leads to large primary surpluses as shown in Figure $4(\mathrm{~g})$, and it is these large primary surpluses that drive down the government debt-output ratio in Figure 4(h). The reduction in this ratio is fairly rapid - under the government spending rule, it takes 6.5 years to close half of the gap between the debt-output ratio at the end of the Great Recession and its target value (94.3\% and $59.1 \%$, respectively).

The macroeconomic channels through which the various tax rates operate are as follows. The labor income tax reduces the contribution of the after-tax real wage to match surplus. The capital income tax affects the after-tax return to capital, and so capital accumulation. There are two effects associated with the consumption tax: the first is to make private consumption more expensive, and so reduces those expenditures; the second operates through the discount factor, $\Delta_{t, t+1}$ in Eq. (5). In the discount factor, the temporal pattern of the consumption tax acts as either a subsidy (when the consumption tax is falling over time), or a tax (when its rising over time) on returns.

To analyze the paths of other macroeconomic variables, it is helpful to think about how the paths would evolve after the Great Recession if the fiscal policy rule were not in play. As the exogenous forcing variables smoothly return to trend, so should all the other variables. 
For the labor market variables, it is the paths associated with the two factor income taxes that come closest to this hypothetical smooth adjustment path. In the government spending scenario, there is a slightly lower vacancy cost just after the Great Recession. This lower vacancy cost leads to more vacancies and so a higher job-finding probability, and ultimately to higher employment and a lower unemployment rate. The opposite situation prevails under the consumption tax: the vacancy cost is higher, and so is the unemployment rate. However, all of these differences are fairly small and fleeting. Averaged over the 12 months following the Great Recession, the unemployment rate is $5.4 \%$ under the two factor income taxes; it is $5.5 \%$ under government spending, and $5.9 \%$ under the consumption tax. In other words, across the four policy instruments, there is at most a 0.5 percentage point difference in the unemployment rate in the first year. There are similarly small differences in the paths for the real wage.

For the remaining macroeconomic variables, it is the labor income tax scenario that produces paths that come closest to the conjectured smooth adjustment path. In this case, at the end of the Great Recession, output, consumption and investment are all close to trend, and exhibit smooth adjustment to their trend paths. With investment simply returning to trend, it takes a considerable period of time for the capital stock to approach its trend.

Under the capital income tax, output, consumption and investment likewise exhibit smooth paths towards trend. An important difference relative to the labor income tax is that the anticipated capital income tax hike after the Great Recession leads to a sizable decline in the capital stock throughout the Great Recession. As a result of the substantially higher capital income tax rate in the post-Great Recession period, investment is well below trend. Another important difference in the paths produced by the two income tax rates is that the real interest rate plummets as the capital income tax rate rises. As discussed earlier, this decline in the real interest rate is a consequence of the fact that the real return to government debt must equal the real after-tax return on capital; this latter return falls sharply in the face of a significant hike in the capital income tax rate. 
It should not be too surprising that the principle effect of using the consumption tax to bring the debt-output ratio back to its pre-Great Recession level operates through private consumption. In particular, consumption falls as the consumption tax is hiked up, and investment more persistently remains below trend. Indeed, the real interest rate falls even more in this case than under the capital income tax.

Finally, when government spending is the policy instrument, the large drop in government spending is associated with an offsetting large increase in private consumption. This rise in consumption can be traced to two factors. First, the drop in government spending frees up resources for both consumption and investment. Second, since households value both private and public consumption goods, smoothing utility in the face of such a large drop in public consumption requires a similarly sizable increase in private consumption. The fact that investment rises above trend leads to a more rapid increase in the capital stock.

\subsection{Welfare Implications}

All of the policies considered involve short run pain in the form of contractionary fiscal policy, in return for a long run gain associated with returning the government debt-output ratio back to its pre-Great Recession level. Here, the question is whether it is better to implement such a reduction in the debt-output ratio through government spending, or one of the taxes. Since the employment rate is $e_{t}$ while the unemployment rate is $u_{t}$, the expected value to a household member of living under the government spending policy is $e_{0} W_{0}^{g}+u_{0} U_{t}^{g}$ where $W_{0}^{g}$ is the value of being a worker and $U_{0}^{g}$ the value of being unemployed, both under the government spending rule. The welfare benefit of using, instead, a tax policy is measured by the fraction $\zeta$ of earnings that can be taken away each period such that the expected value to a typical household member is equal to that obtained under the government spending rule. More specifically, compute

$$
\tilde{W}_{t}^{\tau}=(1-\zeta)\left(1-\tau_{w t}^{\tau}\right) w_{t}^{\tau}+\Delta_{t, t+1}^{\tau}\left[\left(1-s_{t}\right) \tilde{W}_{t+1}^{\tau}+s_{t} \tilde{U}_{t+1}^{\tau}\right]
$$




$$
\tilde{U}_{t}^{\tau}=(1-\zeta)\left(1-\tau_{w t}^{\tau}\right) b+\Delta_{t, t+1}^{\tau}\left[\left(1-f_{t}^{\tau}\right) \tilde{U}_{t+1}+f_{t}^{\tau} \tilde{W}_{t+1}\right]
$$

and adjust $\zeta$ until

$$
e_{0} W_{0}^{g}+u_{0} U_{0}^{g}=e_{0} \tilde{W}_{0}^{\tau}+u_{0} \tilde{U}_{0}^{\tau}
$$

where $g$ superscripts refer to variables obtained under the baseline government spending policy, and $\tau$ superscripts pertain to an alternative, tax-based fiscal policy. ${ }^{11}$

The welfare measure $\zeta$ can alternatively be computed from

$$
(1-\zeta) \sum_{t=0}^{\infty} \Delta_{0, t}^{\tau}\left[\left(1-\tau_{w t}^{\tau}\right)\left(e_{t}^{\tau} w_{t}^{\tau}+u_{t}^{\tau} b\right)\right]=\sum_{t=0}^{\infty} \Delta_{0, t}^{g}\left[\left(1-\tau_{w t}^{g}\right)\left(e_{t}^{g} w_{t}^{g}+u_{t}^{g} b\right)\right] .
$$

On the right-hand side is the present discounted value of earnings and unemployment insurance compensation when government spending satisfies the fiscal policy rule, where the discounting is given by the discount factor $\Delta_{0, t}^{g}$. The sum on the left-hand side has a similar interpretation when a tax rate is the fiscal policy instrument. To convert this measure into a fraction of income, multiply by labor's share of income which, given our calibration, is roughly $0.7{ }^{12}$

Table 2: Welfare Benefit Relative to the Baseline Government Spending Policy

\begin{tabular}{rrrr}
\hline & \multicolumn{1}{c}{$\tau_{w}$} & \multicolumn{1}{c}{$\tau_{c}$} & \multicolumn{1}{c}{$\tau_{k}$} \\
\cline { 2 - 4 }$U_{1}=U_{2}$ & -1.20 & 0.82 & 1.18 \\
$U_{1}<U_{2}$ & -0.80 & 1.19 & 1.80 \\
$U_{1}>U_{2}$ & -2.12 & -0.09 & -0.18 \\
\hline
\end{tabular}

The benchmark case is when $U_{1}=U_{2}$ in steady state which corresponds to setting the parameter on private consumption in the consumption aggregator, $\psi$, so that the marginal utility of private consumption goods equals that of public consumption goods. Welfare results for the benchmark case are reported in the first row in Table 2. For this case, switching from the government spending fiscal policy to the labor income tax results in a welfare loss of $1.20 \%$ of income. In contrast, switching to either the consumption or capital income tax

\footnotetext{
${ }^{11}$ Since the first few periods of the model time paths are influenced by the initial condition, the welfare metric is computed after discarding the first 12 months of these paths.

${ }^{12}$ Labor's share will be a little less than the elasticity of output with respect to labor due to the Nash bargaining-determination of wages.
} 
delivers a welfare gain of $0.82 \%$ or $1.18 \%$, respectively.

The potential welfare benefit (or loss) of switching from government spending to one of the tax instruments is quite large, particularly in light of the relatively minor differences in the model's time paths summarized in Figures 3 and 4. To understand what is driving these welfare numbers, Table 3 isolates the effects of the variables going into the calculation of the welfare metric. For example, the effect of the different employment (and unemployment) paths is obtained by recomputing the welfare metric, $\zeta$, replacing the employment path under the tax policy with the one prevailing under the government spending policy. Subtract this new value of $\zeta$ from the original to obtain the contribution of employment. Repeat for the other variables that factor into the calculation of the welfare benefit.

Across the three taxes, Table 3 shows that the induced differences in either employment or the job-finding probability have essentially no effect on the welfare calculation. The wage rate contributes negatively while the discount factor has a large positive effect. To understand the wage effect, zoom in on Figure 4(f). Relative to the path under the government spending policy, the labor income tax policy exhibits a short, sharp rise in the wage rate just prior to the end of the Great Recession; thereafter, the wage is lower. Under the consumption tax, late in the Great Recession, the wage rate is more persistently above that implied by government spending, but then is quite a bit below. The story is qualitatively similar for the capital income tax. Evidently, the lower wages after the Great Recession (relative to the path under government spending) dominates the welfare computation.

Table 3: Decomposition of the Welfare Benefit Relative to Baseline Government Spending Policy

\begin{tabular}{lrrr}
\hline & \multicolumn{1}{c}{$\tau_{w}$} & \multicolumn{1}{c}{$\tau_{c}$} & \multicolumn{1}{c}{$\tau_{k}$} \\
\cline { 2 - 4 } Employment & 0.000 & 0.000 & 0.000 \\
Job-finding & -0.004 & -0.016 & -0.030 \\
Wage & -0.053 & -0.176 & -0.761 \\
Discounting & 0.288 & 1.006 & 1.970 \\
Labor income tax & -1.435 & & \\
\cline { 2 - 4 } Sum & -1.204 & 0.814 & 1.178 \\
\hline
\end{tabular}


The differential effects of the discount factor, $\Delta_{t, t+1}$, can be inferred from the behavior of private and public consumption. The sharp rise in private consumption at the end of the Great Recession, depicted in Figure 4(b), lowers the future marginal utility of private consumption. In light of the assumed substitutability in utility between private and public consumption, this fall in the future marginal utility of private consumption is partially offset by the fall in government spending. On net, under the government spending policy, the discount factor exhibits a slight decline. In contrast, the tax-based policies feature an increase in the discount factor. In the cases of the income taxes, the modest decline in private consumption dominates the effect of the rise in government spending. When the consumption tax is the policy instrument, both private and public consumption rise, pushing down the future marginal utility of private consumption, and so the discount factor. Here, the sharp increase in the consumption tax rate (from $6.5 \%$ to $9.7 \%$ ) is sufficient to more than offset the influence of private and public consumption on the discount factor, and a sizable increase in $\Delta_{t, t+1}$ is recorded. Table 3 shows that the effects associated with the discount factor are the dominates effects for the consumption and capital income taxes.

The final factor in the welfare calculation is the change in the labor income tax which is only in play when considering this tax rate. The penultimate row in Table 3 reveals that the bulk of the welfare cost associated with switching between the government spending and labor income tax policies is driven by the simple fact that a higher labor income tax rate directly lowers after-tax labor income.

The benchmark calibration of $\psi$ may be considered 'reasonable' in the sense that a benevolent planner choosing private and public consumption would allocate these consumptions to equate their marginal utilities. Yet, this calibration is also somewhat arbitrary. Those on the left of the political spectrum may believe that there is too little public spending. In this case, government spending is quite valuable relative to private consumption, and so $U_{1}<U_{2}$. Calibrate $\psi$ so that $U_{1} / U_{2}=1 / 3$. The dynamic paths of the model for this calibration are quite similar to those of the benchmark calibration and so are omitted. Since the marginal 
utility of public consumption goods is now much higher than that of private consumption goods, households should be more willing to switch to any of the tax-based policies since they are associated with an immediate rise in public consumption. Indeed, the second line in Table 2 shows that this intuition holds: the welfare benefit of switching to either the consumption or capital income taxes is higher, and the welfare loss of switching to the labor income tax is lower.

Alternatively, those to the right of the political spectrum probably think that there is too much government spending. To capture this scenario, calibrate $\psi$ such that $U_{1} / U_{2}=3$. Again, the dynamic paths associated with this calibration are fairly close to those of the benchmark calibration. In this case, a policy switch to using any of the taxes is welfare-reducing. The intuition is the opposite of the previous case: Households care relatively little about the lost public consumption goods associated with using government spending to reduce the debt-output ratio, and so the distortionary effects of the tax rates plays a greater role in their welfare calculus.

\subsection{Robustness}

\subsubsection{Search and Matching versus Walrasian Labor Markets}

How important was it that the benchmark model included search and matching in the labor market? To answer this question, suppose that labor markets are, instead, Walrasian. Preferences are now

$$
\sum_{t=0}^{\infty} \beta^{t} U\left(c_{t}, g_{t}, e_{t}\right)
$$

where all of the notation is as for the benchmark model. Employment, $e_{t}$, is free to vary within a period. The household's budget constraint is now

$$
\left(1+\tau_{c t}\right) c_{t}+k_{t+1}+p_{t} d_{t+1}=\left(1-\tau_{w t}\right) w_{t} e_{t}+\left[1+\left(1-\tau_{k t}\left(r_{t}-\delta\right)\right] k_{t}+d_{t}+T\right.
$$


Relative to the benchmark model, since there is no longer unemployment, there is no unemployment insurance income. Firms now face a sequence of static problems, renting capital and hiring labor on a period-by-period basis. The government behaves as in the benchmark model except that there is no longer an unemployment insurance program to fund.

The utility function is characterized by a constant Frisch labor supply elasticity:

$$
U(c, g, e)= \begin{cases}\ln C(c, g)-\theta e^{1+1 / \kappa} & \text { if } \gamma=1 \\ \frac{\left[C(c, g)^{1-\gamma}\left(1-\theta(1-\gamma) e^{1+1 / \kappa}\right)^{\gamma}\right]-1}{1-\gamma} & \text { otherwise. }\end{cases}
$$

$C(c, g)$ is the same consumption aggregator as in the benchmark calibration. The calibration is as for the benchmark model with the addition that the weight $\theta$ is chosen so that in steady state, households spend $25.5 \%$ of their time working (a figure consistent with U.S. time use surveys; see Gomme and Rupert (2007)), and the Frisch labor supply elasticity, $\kappa$, is set to 1/4 (a value chosen chiefly to be consistent with the available micro-econometric evidence).

Figure 5: Walrasian Labor Markets: Labor Market

(a) Total Factor Productivity

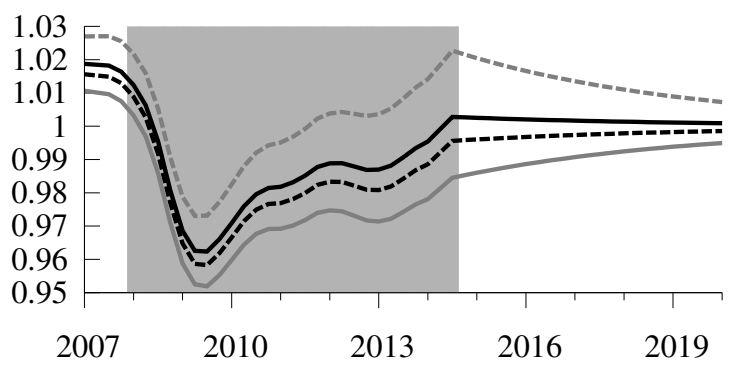

(b) Labor Input

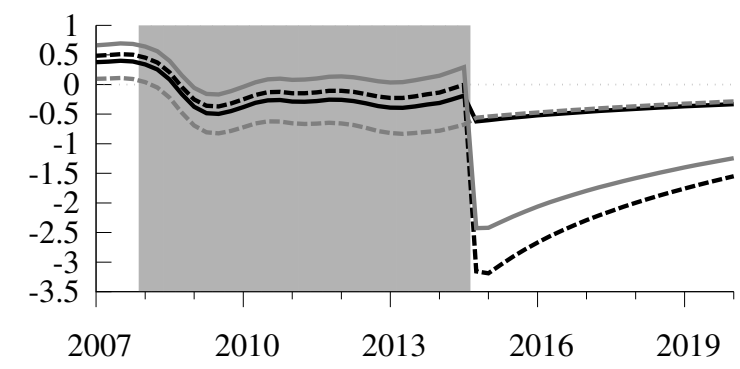

With Walrasian labor markets, total factor productivity has to do much more work during the Great Recession in order for output to track actual; compare Figure 3(h) with Figure 5(a). More specifically, the Walrasian labor market model requires an eight percent drop in total factor productivity from just prior to the Great Recession to the trough; the benchmark (search and matching) model only needs a 2.4 percent fall. The reason for this difference is that the lower job-finding probability in the benchmark model by itself reduces employment 
during the Great Recession. This lower level of employment in the benchmark model serves to reduce output, and total factor productivity does not need to fall as much to match the observed path of output.

The degree of fiscal austerity between the search-and-matching and Walrasian labor markets is quite similar. For example, the benchmark model calls for a 31.4 percentage point increase in the capital income tax rate; the Walrasian model, 36.8 percentage points. The initial increases in the labor income and consumption taxes differ by a few tenths of a percentage point with the Walrasian model calling for slightly more austerity. The changes in government spending are also quite similar.

By construction, during the Great Recession, the path of output matches that observed in the U.S. data; afterwards, output remains close to trend for both the benchmark and Walrasian models. The adjustment cost parameter for the benchmark model was chosen to ensure that the drop in investment was similar to that seen in the data; the Walrasian model uses the same value, $3 / 4$, for this parameter. The paths for investment are broadly similar across the two models. Whereas the benchmark model exaggerates the fall in consumption, the Walrasian model exhibits declines much closer to that seen in the U.S. data. Another significant difference between the two model is that the benchmark model saw a sharp rise in the real wage early in the Great Recession; the Walrasian model predicts a fall.

Turn now to the Walrasian model's predictions for the labor input. Recall that the Frisch labor supply elasticity was chosen to conform with micro-econometric evidence concerning its value; the elasticity was set to $1 / 4$. With this value, the Walrasian model predicts a fall in the labor input of roughly 1\% between 2007 and the trough of the Great Recession; see Figure 5(b). This value is close to the fall in employment over the same time period. When fiscal austerity is applied through the capital income tax, there is almost no effect on employment; under government spending, there is a modest decline. The picture changes a lot under either the labor income or consumption taxes. In these latter cases, the employment responses are substantially larger than those associated with the Great Recession. The 


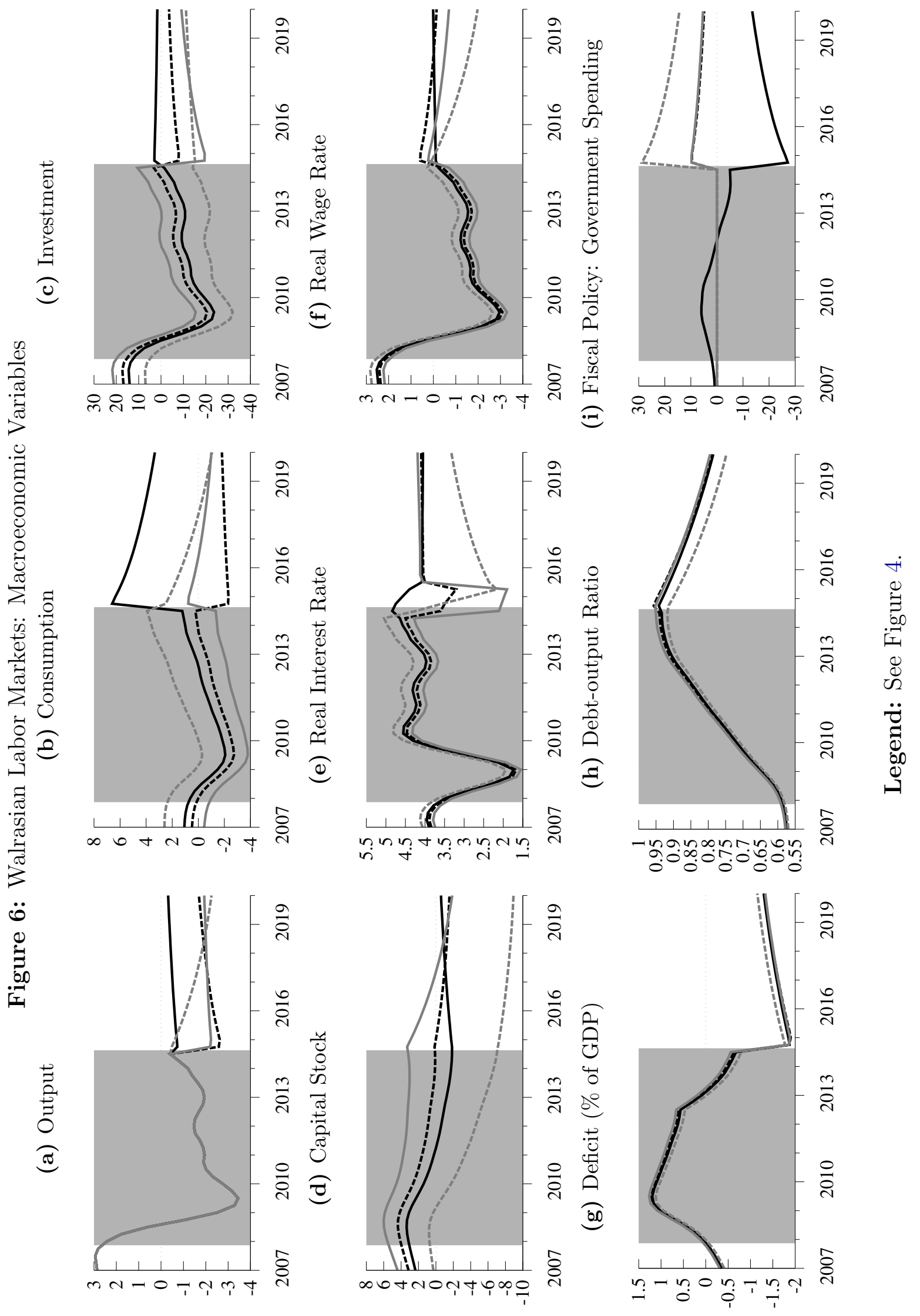


relevant Euler equation is the one governing the labor-leisure choice,

$$
\frac{1-\tau_{w t}}{1+\tau_{c t}} w_{t} U_{1}\left(c_{t}, g_{t}, e_{t}\right)+U_{3}\left(c_{g}, g_{t}, e_{t}\right)=0
$$

which shows that increases in both taxes operate in qualitatively similar ways. Under the labor income tax policy, employment falls by $3 \%$ compared to roughly $0.5 \%$ during the Great Recession. The consumption tax response is smaller $-2.5 \%$ - but nonetheless substantially larger than the employment effects during the Great Recession. These results suggest a weakness in characterizing labor markets as continuous auction markets. Larger labor supply elasticities lead to even larger employment responses both during the Great Recession, and following the application of fiscal austerity. Recall that the benchmark model exhibits a far more modest response of labor to the various fiscal policy instruments. In essence, the Walrasian labor market model suggests that for employment, the fiscal austerity 'cure' to

high debt following the Great Recession is almost as bad as the effects experienced during the Great Recession, at least for the labor income tax and consumption tax.

\subsubsection{Cost of Vacancies versus Match Efficiency}

During the Great Recession, solving the benchmark model involved finding a sequence for the cost of vacancies so that, roughly speaking, the model fits the job-finding probability. As discussed in the introduction, shifts in the Beveridge curve, the empirical relationship between vacancies and unemployment, have lead some to speculate that match efficiency varied during the Great Recession. Suppose that rather than finding a series for the vacancy cost, we instead seek a series for match efficiency so that the model replicates the observed time series for the job-finding probability. Since the model's implications for total factor productivity and macroeconomic variables are quite similar to that of the benchmark model, attention is focused on the labor market implications of this alternative solution.

First off, the model infers a sharp drop off in match efficiency going into the Great Recession; match efficiency continues to drop through 2009. The fall in match efficiency 
Figure 7: Match Efficiency: The Labor Market

(a) Match Efficiency

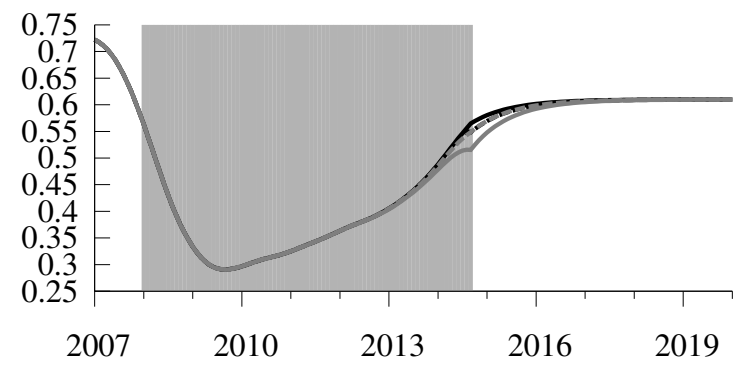

(c) Worker-finding Probability (\%)

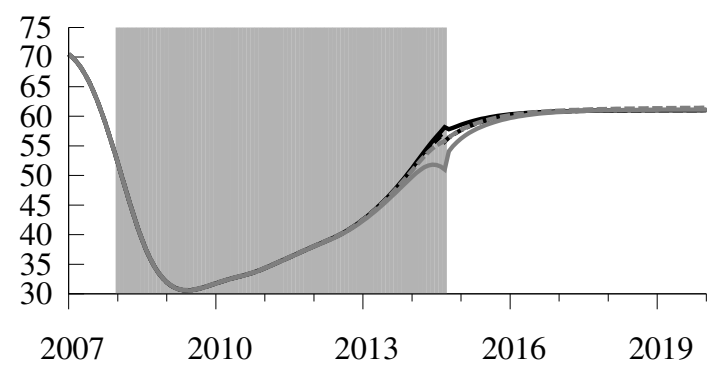

(e) Unemployment Rate (\%)

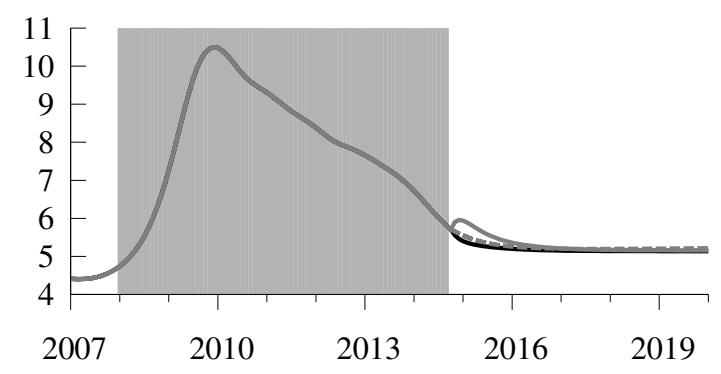

(g) Separation Probability (\%)

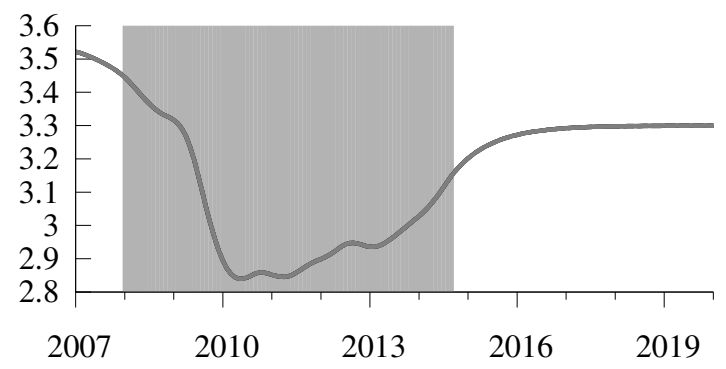

(b) Vacancies (\% deviation)

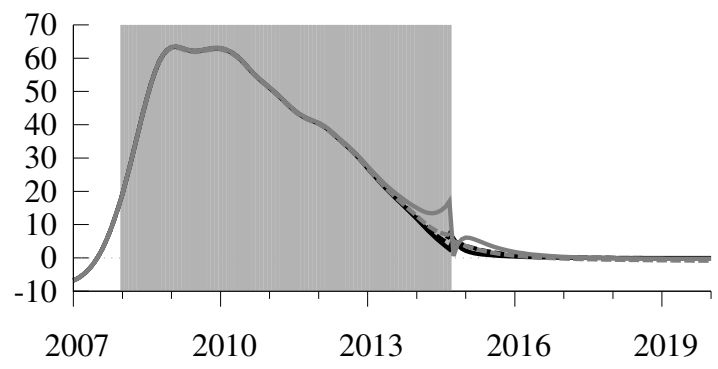

(d) Job-finding Probability (\%)

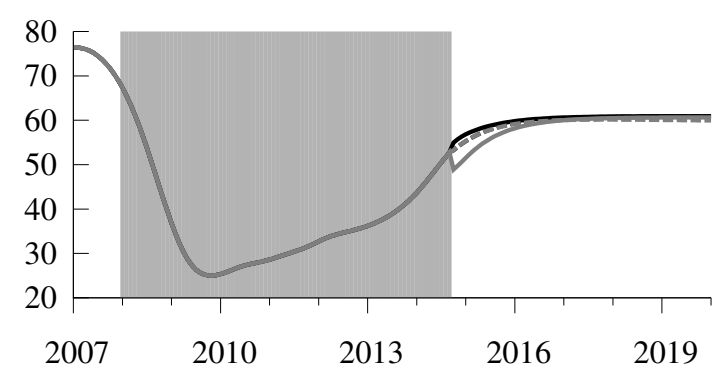

(f) Employment (\% deviation)

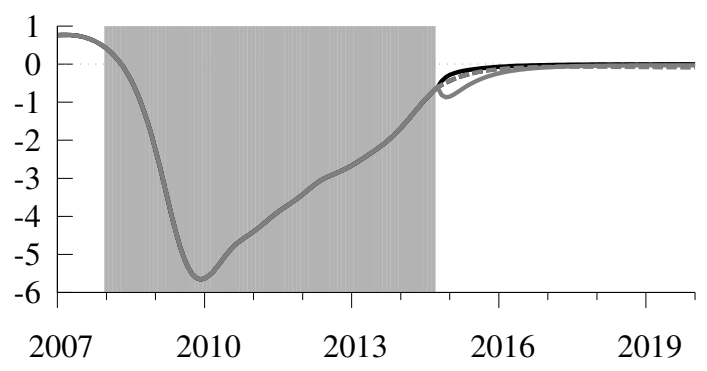

(h) Total Factor Productivity

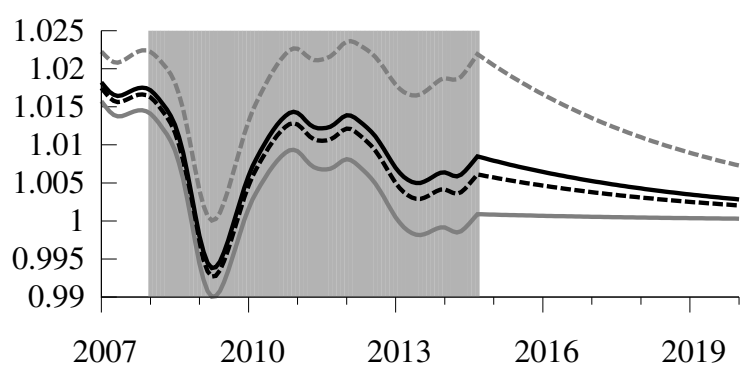

Legend: Solid black lines: government spending; dotted black lines: labor income tax; solid gray lines: consumption tax; dotted gray lines: capital income tax. The shaded area corresponds to the Great Recession period extended to mid-2014 when output returns to its balanced growth path. 
is quite substantial: match efficiency falls from an average of 0.668 in 2007 to as little as 0.292 , a decline of $56 \%$. As with the vacancy cost, it is difficult to directly judge whether the changes in match efficiency over the Great Recession are plausible. However, the model's implications for other variables can be used to indirectly assess the two alternatives, match efficiency or cost of a vacancy. The two alternatives have much different implications for the worker-finding probability. Relative to the average worker-finding probability in 2007, the match efficiency accounting of the Great Recession sees as much as a 33.5 percentage point decline in this probability; the vacancy cost explanation, a 33.2 percentage point increase. As discussed earlier, the benchmark model's predicted decline in the duration of a vacancy, $40 \%$, is close to that reported by Davis, Faberman, and Haltiwanger's (2013) measure for the U.S., 35\%. In contrast, changes in match efficiency imply a increase in the duration of a vacancy, doubling from 1.6 months in 2007 to 3.3 at the depth of the Great Recession.

The fall in the worker-finding probability reported in Figure 7(c) necessitates a large rise in the number of vacancies, Figure 7(b). Again, the benchmark model makes the opposite prediction, a sharp decline in vacancies. For the U.S., Figure 2(d) shows that vacancies dropped during the Great Recession whether measured by the help wanted index (40\%) or job openings $(50 \%)$.

To sum up, choosing match efficiency so that the model's predicted path for workers' job-finding probability matches that seen in the U.S. data leads to counterfactual implications for the behavior of the number of vacancies and the average duration of a vacancy. The benchmark model which chooses, instead, a sequence for the cost of vacancies, is consistent with the data. As a single explanation of the dynamics of the labor market during the Great Recession, match efficiency is clearly lacking

\subsubsection{Parameter Values}

Most of the model parameters or targets, summarized in Table 1, are either commonly used in the business cycle literature (chiefly, preferences and technology), or are well pinned down 
by the data (the tax rates, government's share of output, the government debt-output ratio). Three parameters are relatively new to this paper and so there is less consensus regarding their values: $\omega$, the policy feedback parameter; $\xi$, the elasticity of substitution between private and public consumption goods in preferences; and $\psi$ which governs the importance of private versus public consumption goods in preferences. This section explores how the model's results change with these parameters. One parameter at a time is changed, the model is then re-calibrated and re-solved. Given that two of the three parameters being altered are those that govern the role of public consumption goods in preferences, it should not be too surprising that the results that are most sensitive to these parameters are those associated with using government spending as the policy instrument. With this in mind, and to avoid overwhelming the reader with results, attention is focused on the government spending scenario. These results are summarized in Figures 8 and 9.

To start, consider the effects of setting the policy feedback parameter to a lower value, $\omega=0.05$; in the benchmark calibration, its value is 0.15 . This setting for the policy feedback parameter puts it within the range estimated by Bohn (1998). This lower setting for the policy feedback parameter makes the policy response more gradual. For example, the smaller policy feedback parameter value requires a $7.7 \%$ drop in government spending whereas the benchmark model requires a $23 \%$ fall. The responses under the tax rate policies are similarly moderated when $\omega=0.05$. The net result is a far more gradual response of macroeconomic variables after the Great Recession. It also takes longer to bring down the debt-output ratio; achieving half of the reduction in the debt-output ratio now takes just over 11 years compared to 6.5 for the benchmark setting, $\omega=0.15$.

The other two cases are sufficiently similar to discuss them together. For one, the elasticity of substitution between private and public goods, $\xi$, is set to 0.5 which implies that these goods are much less substitutable in preferences (the benchmark calibration set this parameter to 2); for the other, the parameter $\psi$ is calibrated so that the steady state marginal rate of substitution between private and public consumption goods is 3 ; in the benchmark 


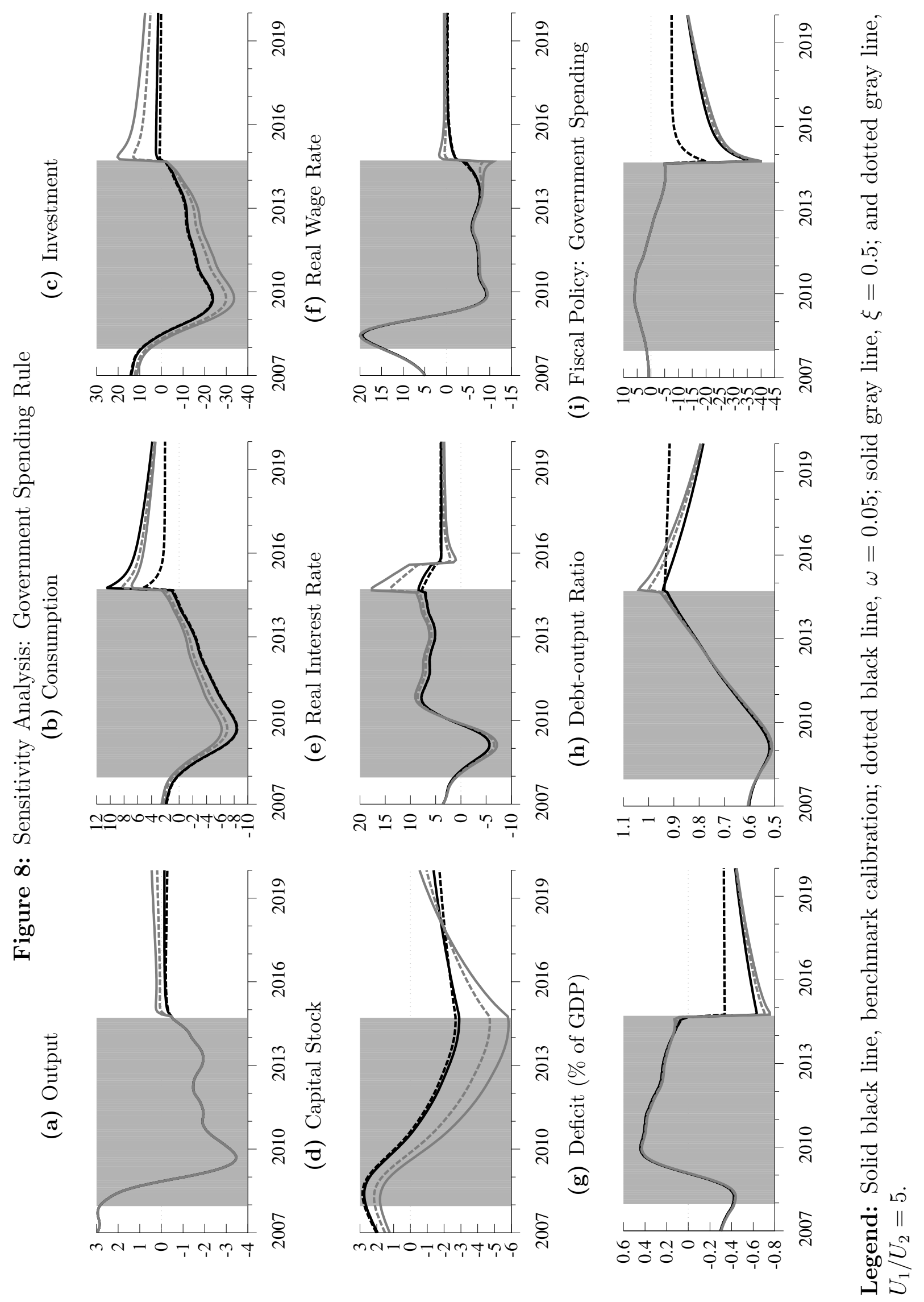


Figure 9: The Labor Market Following the Great Recession
(a) Vacancy Cost
(b) Vacancies (\% deviation)

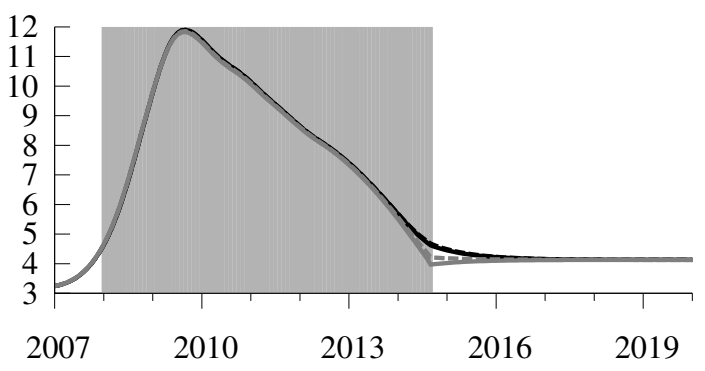

(c) Worker-finding Probability (\%)

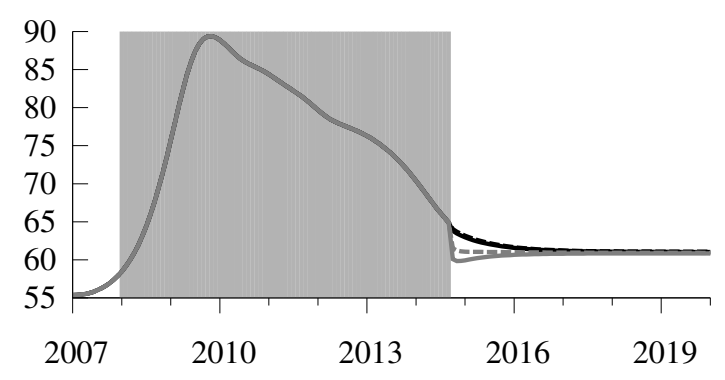

(e) Unemployment Rate (\%)

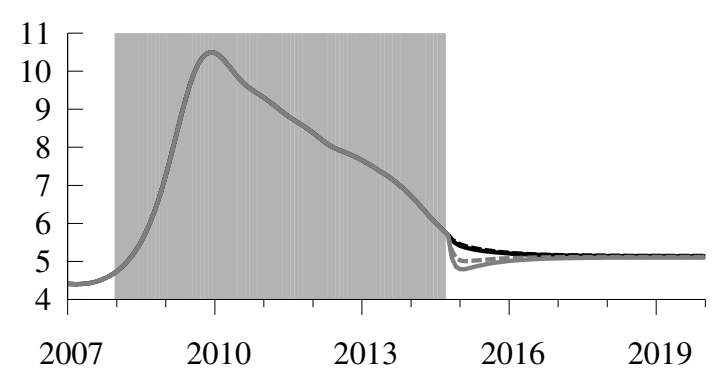

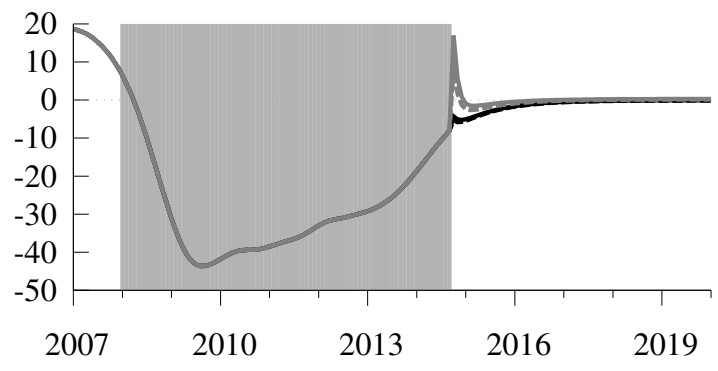

(d) Job-finding Probability (\%)

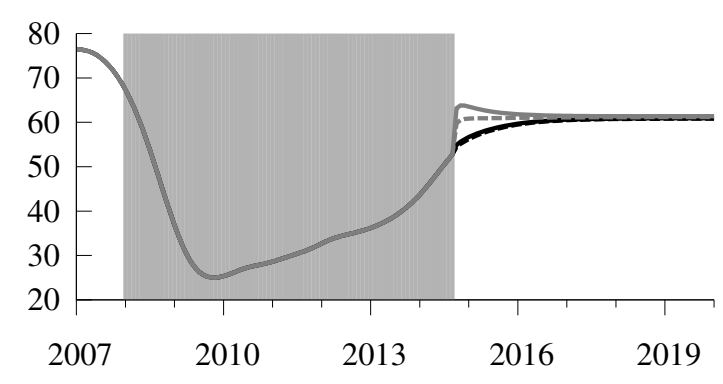

(f) Employment (\% deviation)

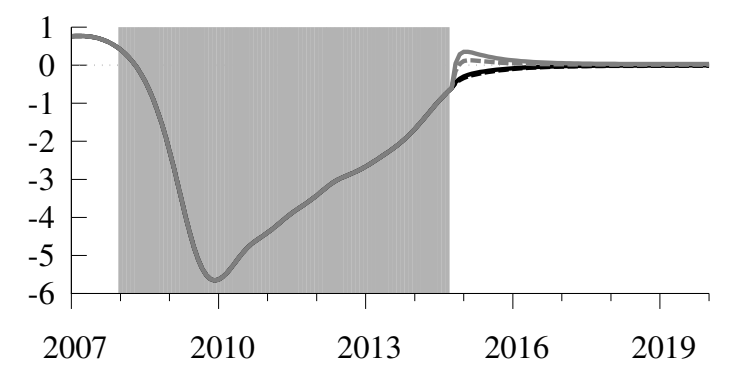

Legend: See Figure 8. 
calibration, the marginal rate of substitution is 1 . Refer to these two cases collectively as the low substitutability calibrations. Consider events during the Great Recession. When private and public goods are less easily substitutable in preferences $(\xi=0.5)$, households' response to the eventual decline in government spending over the last half of the Great Recession is to substitute into private consumption. Given that the model is forced to replicate the path for output during the Great Recession, and since the path for government spending is fixed during the Great Recession, the only way to increase private consumption (relative to the benchmark path) is to reduce investment.

The same mechanics are in operation when the steady state marginal rate of substitution between private and public consumption is 3, but for different economic reasons. Whereas feasibility dictates that the trade-off between private and public consumption goods is 1 , households would be willing to give up closer to 3 units of public consumption goods for an additional unit of private consumption. Faced with a drop in public consumption in the latter half of the Great Recession, households respond by increasing their private consumption (again, relative to the benchmark path). Once again, given the fixed paths for output and government spending, this (relative) increase in private consumption comes at the cost of reduced investment.

Given the lower level of investment, relative to the benchmark path, the capital stock is also lower. The lower capital stock - along with higher total factor productivity - pushes up the real return to capital, and via a no arbitrage condition, the real interest rate on government debt. This higher real interest rate during the Great Recession results in a slightly higher level of government debt: the benchmark model has a debt-output ratio of 0.90 over the last 12 months of the Great Recession; less substitutable private and public consumption results in a ratio of 0.92 while a larger marginal rate of substitution between these two goods sees a ratio of 0.91 . As a result, somewhat greater fiscal austerity is needed relative to the benchmark model. Households increase their consumption in response to the larger drop in government expenditures. The economy increases its investment in order 
to build up its capital stock to allow for above-trend private consumption, and the rising path for government spending that results as the debt-output ratio gradually returns to its pre-Great Recession level.

In fact, for these latter two calibrations, immediately after the Great Recession (as fiscal austerity is being applied) the real interest rate rises which results in an even higher government debt-output ratio: in the first 12 months after the Great Recession, this ratio rises to 1.00 when $\xi=0.5$, or 0.97 when $U_{1}>U_{2}$. Through the fiscal policy rule, these higher debt-output ratios result in even more fiscal austerity: in the first 12 post-Great Recession months, the benchmark calibration calls for government spending $28 \%$ below trend; $\xi=0.5$ results in a larger cut to $30 \%$ below trend. Calibrating to a higher marginal rate of substitution between private and public consumption goods leads to a government spending $29 \%$ below trend.

The labor market implications of these alternative calibrations are largely driven by the dynamics of the vacancy cost. While the $\omega=0.05$ case looks quite similar to that of the benchmark calibration, the low substitutability calibrations do not. Specifically, to fit the data, the low substitutability calibrations require a sharper fall in the cost of vacancies towards the end of the Great Recession; see Figure 9(a). After the Great Recession when the 'natural' dynamics of the model are allowed to operate, these lower vacancy costs result in a spike in vacancies and so the job-finding probability. In turn, this higher probability results in higher employment, and a lower unemployment rate. In the first year after the Great Recession, the benchmark calibration has the unemployment rate sitting at 5.4\%. In contrast, when $\xi=0.5$, the unemployment rate is 5.0 ; for the marginal rate of substitution case, it is 5.1\%. However, as shown in Figure 9(e), these effects are relatively short lived, lasting only a couple of years.

The welfare implications of alternative values of the parameters $\omega$ and $\xi$ are summarized in Figure 10. For the most part, the welfare benefit of switching from government spending to a tax-based policy are not very sensitive to the value of $\omega$ which governs how quickly 
Figure 10: Welfare: Alternative Values of $\omega$ and $\xi$

(a) Welfare Metric for $\tau_{w}$, Varying $\omega$

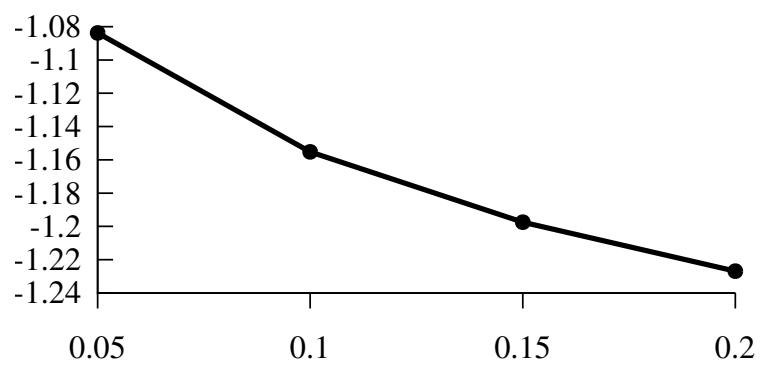

(c) Welfare Metric for $\tau_{c}$, Varying $\omega$

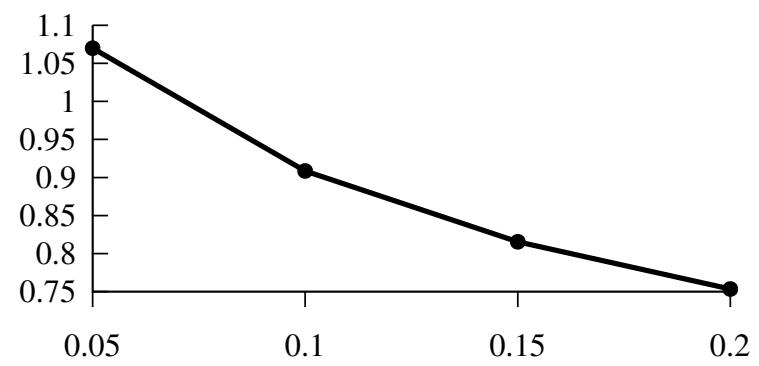

(e) Welfare Metric for $\tau_{k}$, Varying $\omega$

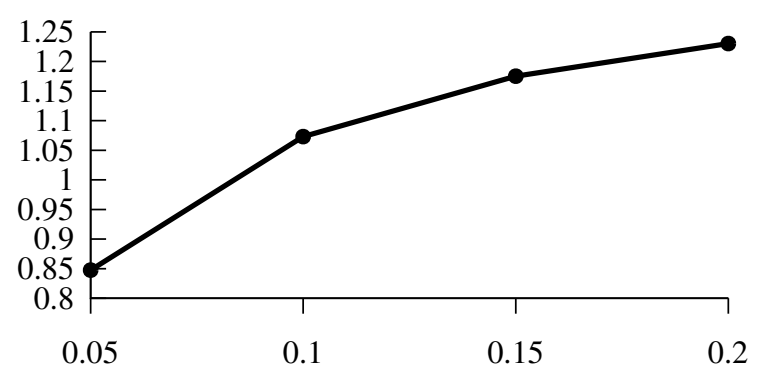

(b) Welfare Metric for $\tau_{w}$, Varying $\xi$

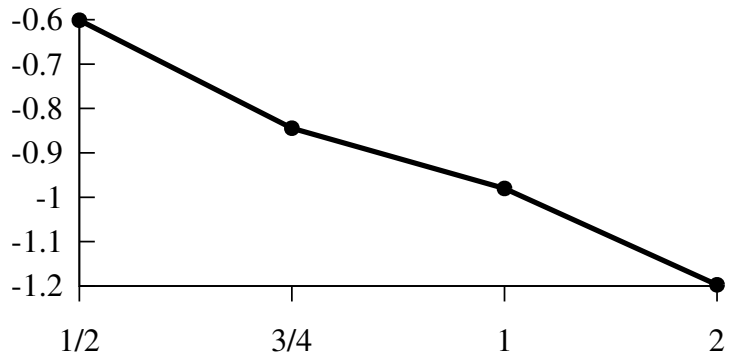

(d) Welfare Metric for $\tau_{c}$, Varying $\xi$

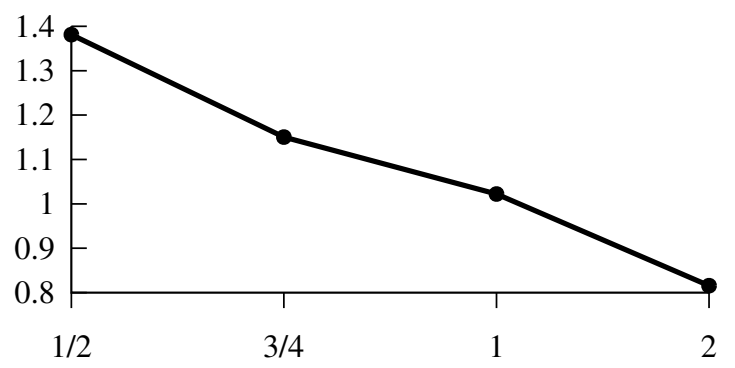

(f) Welfare Metric for $\tau_{k}$, Varying $\xi$

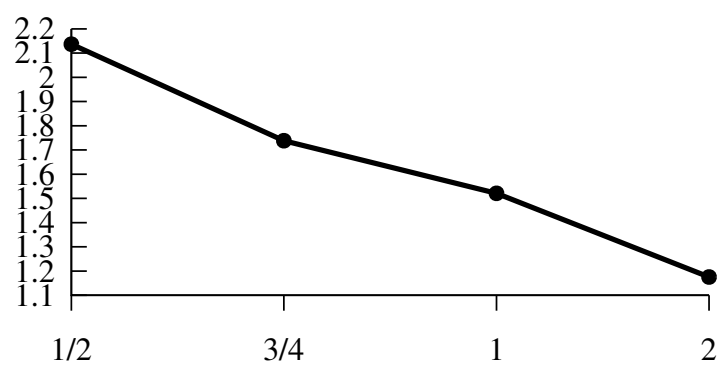

Legend: The vertical axes measure the welfare benefit of switching policy to a particular tax rate. For the left-hand panels, the horizontal axis varies the value of $\omega$ (which governs the degree of policy activism'; the the right-hand panels, the value of $\xi$ (the elasticity of substitution between private and public consumption goods). 
the government returns the debt-output ratio to its pre-Great Recession value. That said, smaller values of $\omega$ (implying a longer transition) are associated with larger welfare benefits of switching from government spending to the consumption tax, and lower benefits of switching to the capital income tax.

The right-hand panels of Figure 10 show that the welfare results are more sensitive to the elasticity of substitution between private and public consumption, $\xi$. In particular, high elasticities are associated with larger welfare benefits of switching the policy instrument from government spending to a tax. This finding is easy to understand: when these goods are more substitutable, households place greater value in the immediate jump in the provision of public goods under a tax-based policy as opposed to the large drop when government expenditures are the policy instrument.

\section{Conclusion}

Motivated by a number of Great Recession facts, in particular, the run-up in government indebtedness, we constructed a dynamic general equilibrium model in order to analyze fiscal policies designed to lower the government debt-output ratio back to its pre-Great Recession value. Key model features are: valued government spending; search and matching in the labor market; and a parsimonious fiscal policy rule that requires the application of fiscal austerity when the debt-output ratio is above its desired level. Processes for government spending and the job separation probability were taken directly from the data; processes for total factor productivity and the cost of a vacancy were chosen so that the model matched observed U.S. output and job-finding probabilities. Overall, the model provides a pretty good fit with the data during the Great Recession which we take as starting in December 2007 and ending in September 2014 when output finally returned to trend. These results lend greater confidence in the prescriptions following from the fiscal policy experiments that come online right after the Great Recession. With the exception of reducing government debt though government 
spending cuts, the macroeconomic disruptions of the alternative public policies considered are relatively mild. That said, since the model is solved under perfect foresight, the large tax increases when the capital income tax is the policy instrument depresses investment and capital over the entire simulation horizon, including the Great Recession. Labor markets are remarkably insensitive to the choice of policy instrument suggesting that fiscal policy simply does not matter much for the labor market.

Welfare benefits of switching from the government spending policy instrument to a tax-based instrument were computed. Switching to the labor income tax was found to be welfare-reducing, principally due to the direct effects of lower after-tax labor income. Switching to either the consumption tax or the capital income tax was found to be welfareenhancing; for these taxes, the benefit of higher public spending outweighs the deleterious effects of additional tax distortions. For the benchmark model, debt reduction implemented through the capital income tax is somewhat preferred to doing so via the consumption tax.

There are a couple of interesting extensions that are left for future work. First, the simple policy rule used above does not address issues like the optimal mix of policy instruments, nor does it say how quickly debt should be reduced. Second, a quantitative assessment of (the possibility of) sovereign default would be interesting, particularly in the European context. 


\section{Appendix A Data Sources}

All data downloaded from https://research.stlouisfed.org/fred2. Codes and descriptions are as follows:

UNRATE: Civilian Unemployment Rate

UNEMPLOY: Unemployment Level

UEMPLT5: Number of Civilians Unemployed for Less Than 5 Weeks

CE16OV: Civilian Employment

JTSJOL: JOLTS: Job Openings: Total Nonfarm

JTSTSL: JOLTS: Total separations: Total Nonfarm

JTSQUR: JOLTS: Quits: Total Nonfarm

JTSHIL: JOLTS: Hires: Total Nonfarm

PCECC96: Real personal consumption expenditures

GCEC96: Real Government Consumption Expenditures \& Gross Investment

GPDIC96: Real Gross Private Domestic Investment, 3 decimal

GDPC96: Real Gross Domestic Product, 3 Decimal

CNP16OV: Civilian Noninstitutional Population

DPCERD3Q086SBEA: Personal consumption expenditures (implicit price deflator)

USREC: NBER based Recession Indicators for the United States from the Period following the Peak through the Trough

GFDEGDQ188S: Federal Debt: Total Public Debt as Percent of Gross Domestic Product

M318501Q027NBEA: Federal government budget surplus or deficit (-) 


\section{References}

Auray, Stéphane, Aurélien Eyquem, and Paul Gomme. forthcoming. "A Tale of Tax Policies in Open Economies." International Economic Review .

Barnichon, Regis. 2010. "Building a Composite Help-Wanted Index." Economics Letters 109 (3):175-178.

Bohn, Benning. 1998. "The Behavior of U.S. Public Debt and Deficits." Quarterly Journal of Economics 113 (3):949-963.

Christiano, Lawrence J., Martin S. Eichenbaum, and Mathias Trabandt. 2015. "Understanding the Great Recession." American Economic Journal: Macroeconomics 7 (1):110-167.

Corsetti, Giancarlo, Keith Kuester, André Meier, and Gernot J. Müller. 2010. "Debt Consolidation and Fiscal Stabilization of Deep Recessions." American Economic Review 100 (2):41-45. URL http://dx.doi.org/10.1257/aer.100.2.41.

Davis, Steven J., R. Jason Faberman, and John C. Haltiwanger. 2013. "The EstablishmentLevel Behavior of Vacancies and Hiring." Quarterly Journal of Economics 128 (2):531-580.

Diamond, Peter A. and Ayşegül Şahin. 2014. "Shifts in the Beveridge Curve." Staff Report 687, Federal Reserve Bank of New York.

Elsby, Michael W. L., Bart Hobijn, and Ayşegül Şahin. 2010. "The Labor Market in the Great Recession." Brookings Papers on Economic Activity 41 (1):1-69.

Elsby, Michael W. L., Bart Hobijn, Aysegul Sahin, and Robet G. Valletta. 2011. "The Labor Market in the Great Recession - An Update to September 2011." Brookings Papers on Economic Activity (Fall).

Erceg, Christopher J. and Jesper Linde. 2013. "Fiscal Consolidation in a Currency Union: Spending Cuts vs. Tax Hikes." Journal of Economic Dynamics and Control 37 (2):422-445. 
Furlanetto, Francesco and Nicolas Groshenny. 2013. "Mismatch Shocks and Unemployment During the Great Recession." Working paper, Norges Bank.

Gomme, Paul and Peter Rupert. 2007. "Theory, Measurement, and Calibration of Macroeconomic Models." Journal of Monetary Economics 54 (2):460-497.

Hobijn, Bart and Ayşegül Şahin. 2013. "Beveridge Curve Shifts across Countries since the Great Recession." Working Paper 2012-24, Federal Reserve Bank of San Francisco.

Mendoza, Enrique G., Assaf Razin, and Linda L. Tesar. 1994. "Effective Tax Rates in Macroeconomics: Cross-Country Estimates of Tax Rates on Factor Incomes and Consumption." Journal of Monetary Economics 34 (3):297-323.

Mendoza, Enrique G., Linda L. Tesar, and Jing Zhang. 2013. "Saving Europe?: The Unpleasant Arithmetic of Fiscal Austerity in Integrated Economies." University of Michigan.

Nukic, Senada. 2014. "Fiscal Consolidation and Employment Loss." MPRA Paper 60224, University Library of Munich, Germany. URL http://ideas.repec.org/p/pra/mprapa/ 60224.html.

Petrongolo, Barbara and Christopher A. Pissarides. 2001. "Looking into the Black Box: A Survey of the Matching Function." Journal of Economic Literature 39 (2):390-431.

Ravn, Morten O. and Harald Uhlig. 2002. "On Adjusting the Hodrick-Prescott Filter for the Frequency of Observations." Review of Economics and Statistics 84 (2):371-380.

Sala, Luca, Ulf Söderstrom, and Antonella Trigari. 2012. "Structural and Cyclical Forces in the Labor Market during the Great Recession: Cross-Country Evidence." In NBER International Seminar on Macroeconomics 2012, NBER Chapters. National Bureau of Economic Research, Inc, 345-404.

Shimer, Robert. 2005. "The Cyclicality of Hires, Separations and Job-to-Job Transitions." Federal Reserve Bank of St. Louis Review 87 (4):493-507. 